\title{
TBBM 21. DÖNEM YASAMA ETKİNLİĞİ VE MİLLETVEKİLI̊ DAVRANIŞI
}

\author{
Haluk ALKAN ${ }^{I}$, Nuh ATES ${ }^{2}$, \\ ${ }^{I}$ K.S.Ü. Kamu Yönetimi Bölümü, Yardımcı Doçent Dr. \\ ${ }^{2}$ K.S.Ü. Kamu Yönetimi Bölümü, Araştırma Görevlisi
}

\section{THE LEGISLATIVE EFFORTS OF THE $21^{\text {ST }}$ TERM \\ GRAND NATIONAL ASSEMBLY OF TURKEY AND \\ POLITICAL BEHAVIOUR OF DEPUTIES}

Abstract: This study is aimed at determining the political attitudes of the deputies within the context of legislative proposals during the 21st term of the Turkish Grand National Assembly. First of a theoretical framework is given. Various classifications according to the deputies' relations with their constituents, their intentions towards legislative process, and their areas of interests are analysed. In addition, the results of previous studies undertaken concerning the TGNAare indicated. In the light of this theoretical framework, the legislative proposals given by deputies individually during the 21 st term are taken as the basis of the study. The paper analyzes these political attitudes that are grouped under general effectivenes, national arrangments, local interests, occupational interests, political life, and party politics. Each of the attitudes are assessed with respect to the province-region, party, and occupation of the deputies. Finally, the paper summarizes the results reached throughout the study.

Keywords: Turkish Parliament, Roles of Deputy's, Policy Making, Political Parties in TBMM

\section{GíRis}

Meclisler, çağdaş demokrasilerde yasama iktidarının temsil edildiği, vatandaşların kural koyma iktidarına katılımının somutlaştığı siyasal kurumlardır. Aynı zamanda bu kurumlar, toplumsal grupların, kurumsallaşmanın, farklı çıkar ve siyasal programların yansımasını bulduğu, bir yerde ülkenin toplumsal dokusuna 1şık tutan sosyal bir yapıyı oluşturmaktadırlar. $\mathrm{Bu}$ nedenle siyasal bilim açısından parlamentoların kurumsal yapıları, işleyiş biçimleri, bileşimi, ürettiği kuralların niteliği ve arka planı önemli araştırma konularının başında gelmektedir. Meclislerin belirleyici aktörleri olan milletvekillerinin nitelikleri, kökenleri, davranış eğilimleri de bu çerçevede araştırmacıların ilgisini çeken konuların birini oluşturmaktadır.

Meclis içinde milletvekillerinin gösterdikleri davranış eğilimleri farklı açılardan incelenip sınıflandırılmıştır. Bu sınıflandırmalardan ilki bir temsilci olarak kendini seçenlere karşı konumunu nasıl algıladığını sorgulamaktadır. Turan'ın belirlediği şekilde Wahlke ve

\section{TBBM 21. DÖNEM YASAMA ETKINNLİĞI VE MILLLETVEKILI DAVRANIŞI}

Özet: Çalışma milletvekili davranışlannın, Türkiye Büyük Millet Meclisi 21. Dönem yasama etkinliği kapsamında nasıl bir yönelime sahip bulunduğunu belirlemeyi amaçlamaktadır. Öncelikle konunun teorik çerçevesi ele altnmaktadvr. Milletvekillerin seçmenleriyle olan ilişkilerine gore, yasam sürecine yönelimierine gore, ilgi alanlarına gore yapılan çeşitli sinuflandirmalar incelenmektedir. Ayrica TBMM üzerinde yapılan önceki çallş̧malartn sonuçlan verilmektedir. Bu teorik çerçevenin tş̆ğında 21. Dönem yasam etkinliği çerçevesinde milletvekillerinin kendi inisiyatiflerine tantnmıs bulunan yasa önerileri temel alınmaktadır. Milletvekili eğilimleri, genel etkinlik; ulusul düzenlemeler; yerel çıkarlar; uğraş alanına ait çlkarlar; siyasal hayat ve parti politikalan olmak üzere beş düzeyde ele altnip incelenmektedir. Her bir eğilim, milletvekilinin ili-bölgesi, üyesi bulunduğu parti ve uğraş alanı açısından ayn ayn değerlendirilmektedir. Ulaşılan sonuçlar çalışmanin sonuç kısminda özetlenmektedir.

Anahtar Kelimeler: Türk Parlamentosu, Milletvekili Rolï, Siyasal Yaptm Süreci, TBMM'de Siyasal Partiler

arkadaşları Amerikan Eyalet Meclisleri'nde yaptıkları incelemede bu açıdan üç tip milletvekili davranışı belirlemişlerdir. Bunlar delege, vasi ve karma tiplerdir. Delegeler kendilerini seçen grupların taleplerine oldukça duyarlı şekilde hareket etmektedirler. Vasi tipindeki milletvekilleri ise tam tersine seçmenlerden çok kendi yargıları doğrultusunda hareket etmektedirler. Karma tipteki milletvekilleri ise seçmen talepleri ile kendi yargılarını bağdaştırmaya çaba harcayan, zaman zaman kendilerinin, zaman zaman da seçmen taleplerini öne çıkaran bir davranış eğilimine sahip bulunmaktadırlar [8].

İkinci bir sınıflandırma milletvekillerinin yasama sürecine yönelimlerini temel alır. $\mathrm{Bu}$ ayrıma göre, milletvekili etkinlik alanı olarak Meclis çatısı altındaki kurallar ve işlemlere ağırlık veriyorsa, başka bir ifade ile komisyonlara katılım, yasa önerileri sunmak, meclis işleyişi ile ilgili görevler üstlenmek yönünde çaba harcıyorsa törensel; buna karşılık meclis dışı etkinlikler üzerinde yoğunlaşıyorsa, iş takibi yapmak gibi, fırsatçı bir davranış eğilimine sahip bulunmaktadır [1]. 
Üçüncü bir ayrım milletvekilinin yasama sürecindeki yönelim alanlarına göre şekillenir. Buna göre milletvekilleri parti politikalarını, yerel çıkarları, ulusal çıkarları önceleyen farklı yasama yönelimlerine sahip olabilirler. Kaynakların kıt olması bu kaynakların dağıtımı konusunda rekabeti zorunlu kılmaktadır. Dolayısıyla milletvekilleri de Mecliste temsilen geldikleri bölgelerin çıkarları konusunda rekabet içerisindedirler. Benzer şekilde, yerel düzeyde siyasaların uygulanmasından sorumlu bürokratların yönlendirilmesinde, seçmenler genellikle milletvekillerini bir nüfuz kanalı olarak kullanmak istemektedirler. Bu zorunluluklar milletvekillerini yerel çıkarlara duyarlı kılmaktadır [10]. Ancak bu her zaman geçerli bir olgu değildir. Özellikle milletvekillerinin seçilmelerinde parti politikalarının belirleyici olduğu; disiplinli parti rejimlerinin hakim bulunduğu, yasama sürecinde meclis grubu disiplininin önem kazandığ milletvekili rolü, yerelden çok parti politikalarını önceleyen bir görünüm kazanabilir. $\mathrm{Bu}$ açıdan $\mathrm{ABD}$ Kongresi ile İngiltere Avam Kamarası örnekleri karşıt iki örneği oluşturmaktadır [7]. Buna daha kozmopolit ve kalabalık kent merkezlerinden gelen milletvekilleri üzerinde yerel talep baskısının azalacağı, dolayısıyla bu milletvekillerinin yerel çıkarlardan çok ulusal düzenlemelere dönüik bir yasama sürecine yönelecekleri varsayımını ekleyebiliriz. Aynı şekilde yasama yöneliminde uğraş alanına ait kimlikler ve çıkarlara dönük bir davranış eğilimi de güç kazanabilir. Baskı grupları olarak farklı grupları temsil eden örgütler hem lobicilik yapmak suretiyle milletvekillerini yönlendirmek, hem de bizzat kendi temsilciliklerini milletvekili olarak parlamentoya sokarak çıkarları doğrultusunda bir yasama etkinliğinin gerçekleştirilmesine çaba harcayabilirler [5].

Türkiye Büyük Millet Meclisi (TBMM) üzerinde milletvekili davranışları ile ilgili farklı araştırmalar yapılmıştır. Kalaycıoğlu 1984 yılında 125 milletvekili ile yaptığı görüşmelere dayanan çalışmasında, milletvekili davranışına etki eden talep mekanizması üzerinde durmaktadır. Bu çalışmada seçmenin doğrudan kendini ilgilendiren talepleri daha fazla öne çıkardığı, bu talepler üzerinden milletvekili ile temasa geçtiği görülmektedir. Genel kamu siyasası, yereli ilgilendiren talepler ve kişiye özgü taleplerin çok gerisindedir [2]. Bu talep profili, milletvekillerinin kamu siyasasını yönlendirecek yasama etkinliklerinden çok meclis dışı etkinliklere daha çok zaman ayırması gibi bir sonuç doğurabilir. Nitekim aynı çalışmada seçmen taleplerine ayrılan süreye zamanının yarısı ve daha fazlasını ayırdığını belirten milletvekili oranı \%74'ü bulmaktadır [2]. Kalaycıoğlu yerel planda kişiye özgü taleplerin ve topluluğa hizmet sunulmasını amaçlayan taleplerin, siyasal temsil ilişkisinde ağırlık kazandığını vurgulamaktadır [2].

Turan, milletvekili davranışında seçmenlerine kazanım sağlamanın genel yasama etkinliginin önüne geçtiğini vurgulayarak, bu milletvekillerinin hükümet ve bürokrasiye nüfuz açısından bağlı oldukları parti iktidarda ise bu kazanımları daha kolay sağlayabildiklerinden uysal bir tutuma yöneldiklerini, tersi bir durumda ise partisine bağlılığının azaldığını belirtmektedir. Turan, Türk yasama sistemindeki yüksek dönüş oranı ve seçmenlere dönük eg̛ilimin, milletvekillerinde seçmenlerine iş ve kazanım sağlayacak pozisyonlara geçme, meclis çalışmalarına devam etmeme, bir daha seçilememe olasılığının yüksekliği nedeniyle bireysel çıkarını maksimize etmeye yönelme, dolayısıyla bazı özel ayrıcalıklar edinmeye çalışma gibi davranışlar beklediğini ileri sürmektedir. Turan, genel olarak iktidar ve muhalefet partilerinin meclisi birbirleri ile bir çatışma alanı olarak görme eğiliminde olduklarını dolayısıyla muhalefetin meclisi, yasama sürecini bloke etmek ve hükümeti etkisiz bırakma yönünde kullanmaya çabaladığını da vurgulamaktadır [9].

Kalaycıŏlu yasama sürecindeki kesintilerin, Meclis'in kurumsallaşma sürecine de olumsuz etki yaptığını belirleyerek, bunun kural dışı davranış eğilimini yükselten bir faktör olduğunu ileri sürmektedir [3]. Yine seçmenle patron ilişkilerine dayalı milletvekili davranışının, yasama organının kurumsal yozlaşması için elverişli bir ortam sağladığını vurgulamaktadır [4].

Genel olarak Türk yasama sisteminde milletvekili davranışının, kişisel talep ağırlıklı ve parlamento dışı etkinlik alanına yönelik, kurumsallaşamamanın getirdiği bir profesyonelleşme yetersizliğinin var olduğu, dolayısıyla kurumsal yozlaşma potansiyelinin bulunduğu bir kurumsal zeminde şekillendiği belirtilebilir.

Buna karşılık milletvekili davranışının, yasama etkinliği kapsamında nasıl bir yönelime sahip bulunduğu yeterince irdelenmemiştir. Milletvekilleri kendi inisiyatiflerine tanınmış bulunan yasa önergelerinde hangi yönelimlere sahiptirler? Bu yönelimleri belli çıkar alanları çerçevesinde anlamlandırmak mümkün müdür? Yine milletvekillerinin partisel ve kişisel nitelikli yönelimlerinde belirleyici bir faktör oluşturmakta mıdır? Çalışmamız bu çerçevede 21. dönem TBMM yasama dönemini temel alarak Türk yasama sisteminde milletvekili etkinliğinin bu görünümünü belirlemeyi amaçlamaktadır.

\section{ARAŞTIRMA YÖNTEMİ ve SINIRLILIKLAR}

Belirtildiği gibi çalışma 21. Dönem yasama etkinlikleri kapsamında Meclis komisyonlarına gönderilmiş yasa önerilerinin sınıflandırılarak, milletvekillerinin yasamaya ilişkin rollerinin çeşitli değişkenler ışığında belirlenmesini amaçlamaktadır. Bu doğrultuda toplam 1047 yasa önergesi incelenerek kendi içlerinde aşağıdaki başlıklar altında sınıflandırılmıştır.

- Ulusal boyutta düzenleme getiren yasa önerileri

- Yerel çıkarlara yönelik olarak verilen yasa önerileri 
- Uğraş alanlarına ait çıkarlara yönelik olarak verilen yasa önerileri

- Parti politikaları dogrultusunda ve siyasal hayatın düzenlenmesine yönelik olarak verilen yasa önerileri

- Spesifik çıkarlara dönük yasa önerileri

Sınıflandırma kapsamında her bir başlık altında değerlendirilen yasa önerilerinin sayıları Tablo.1'de verilmektedir.

Tablo.1: Yasa Önerilerinin Sınıfland̊rılması

\begin{tabular}{lrcc}
\hline Yasa Oூnerilerinin Sınıflandırılması & N & \% \\
\hline Ulusal boyutta yasa önerileri & 247 & 23,6 \\
$\begin{array}{l}\text { Yerel çıar yasa önerileri } \\
\text { Uğraş alanına ait çıkar yasa önerileri }\end{array}$ & 366 & 34,9 \\
$\begin{array}{l}\text { Parti politikaları doğrultusunda yasa } \\
\text { önerileri }\end{array}$ & 243 & 12,8 \\
$\begin{array}{l}\text { Siyasal hayatın düzenlenmesi yasa } \\
\text { önerileri }\end{array}$ & 42 & 4,1 \\
$\begin{array}{l}\text { Spesifik çıkar yasa önerileri } \\
\text { Toplam }\end{array}$ & 15 & 1,4 \\
\hline
\end{tabular}

Çalışma kapsamında spesifik çıkarlara yönelik yasa önerileri sayıca az olmaları nedeniyle, değerlendirme dışında tutulmuş, diğer 4 başlık, milletvekillerine bağlı değişkenler ş̧ı̆̆ında incelenmiştir. Milletvekillerinin sınıflandırmaya paralel olarak davranış eğilimlerinin belirlenmesinde, örneklemi oluşturan 548 milletvekilinin özgeçmişleri incelenmiş, imza verdikleri yasa önergeleri belirlenmiştir. Çalışmada milletvekillerinin (Bkz. Tablo.2), cinsiyeti, doğum tarihi, ögrenim durumu, temsil ettiği il ve bölgesi, partisi, uğraş alanı bağımsız değişken olarak alınmıştır. Cinsiyet, yaş ve ögrenim durumu genel yasama etkinliği analiz edilirken inceleme kapsamına alınmış, diğer konularda il-bölge, parti ve uğraş alanı değişkenleri ışığında milletvekili davranışları incelenmiştir. Böyle bir ayrımın yapılma nedeni, Meclis'teki dağılımların değerlendirmeye olanak vermemesidir. Örneğin cinsiyete bağl1 bir değerlendirmede kadın milletvekili sayısının azlığı karşılaştırma yapmayı mümkün kılmamaktadır. Yine 548 milletvekilinin 500'ü yüksek öğrenim görmüş kişilerden oluşmaktadır. Dolayısıyla ögrenim durumu kategorilerinde sağlıklı bir karşılaştırma yapılamamaktadir.

Ayrıca çalışmanın sınırlılıkları şu şekilde sıralanabilir. Öncelikle, çalışma yalnızca yasa önerilerini kapsamakta, bunun dışındaki milletvekili rolü açısından açıklayıcı olan meclis kararları ve denetleme mekanizmaları ile ilgili etkinlikleri inceleme dışında bırakmaktadir.

İkinci olarak kategorileştirme milletvekiline özgü yapıldığından mesleki yasa önerileri sınıflandırılmasında bir zorluk bulunmaktadır. Bir uğraş alanına mensup mill milletvekilinin kendi konusunda bir öneri vermesi kolaylıkla anlaşılabilir. Ancak öneriye imza veren diğer milletvekilinin aynı uğraş alanından olmaması durumunda bir belirsizlik ortaya çıkmaktadır. Çalışmada milletvekili esas alındığından, o kişi için uğraş alanı olarak değerlendirilen öneri, diğer milletvekili için genel kategorisi içinde değerlendirilmektedir. Bunun nedeni böyle bir öneriye imza atan milletvekilinin önerisi genel anlamda faydalı olarak değerlendirmesi, kendisini ilgilendirmese de milletvekili arkadaşlarının isteğini kırmayarak imza atması veya dolaylı olarak kendisine seçmen ve yakınları tarafından bu yönde istemde bulunulması gibi farklı nedenlerle hareket etme olasılığı ve bunun belirlenmesinin olanak dışı olmasıdır. Bu nedenle imza veren milletvekili ile dogrudan bağlantılı olmayan önerilere ulusal düzenleme içinde yer verilmektedir.

Diğer bir sınırlılık milletvekilinin partilere göre dağılımıyla ilgilidir. Bilindiği gibi 21. dönem, Meclis'e giren partiler içinde bölünmelerin yaşandığı bir dönemdir. AKP, BBP, CHP, ÖDP, YTP, YP sonradan Meclis içinde oluşmuş partilerdir. Çalışmada partiler, Meclis'e girdikleri şekliyle gruplandırılmış, bağımsız üyelerde ise Meclis'teki son dağılım temel alınmıştır.

Tablo.2: Milletvekillerinin Bölge,Cinsiyet,Doğum Tarihi,Öğrenim Durumu,Uğraş Alanı ve Partilere Göre Dağılımu

\begin{tabular}{|c|c|c|c|c|c|c|c|c|c|c|c|}
\hline M.nin Bölgesí & $\mathbf{N}$ & $\%$ & $\begin{array}{l}\text { M.nin Dğm } \\
\text { Trh }\end{array}$ & $\mathbf{N}$ & $\%$ & M.nin Uğraş Alanı & $\mathbf{N}$ & $\%$ & M.nin Partisi & $\mathbf{N}$ & $\%$ \\
\hline Marmara & 129 & 23,6 & $1911-1920$ & 2 & 0,4 & Ögretim Üyesi & 64 & 11,6 & ANAP + YP & 75 & 13,6 \\
\hline Ege & 71 & 12,9 & $1921-1930$ & 14 & 2,6 & Bürokrat & 74 & 13,5 & DYP & 82 & 15 \\
\hline \multirow[t]{2}{*}{ Akdeniz } & & & $1931-1940$ & 60 & & Sğlk Gr. Ser Mes. & 46 & & $\mathrm{DSP}+\mathrm{YTP}$ & & \\
\hline & 68 & 12,5 & & & 10,9 & & & 8,4 & $\mathrm{CHP}+\mathrm{ÖDP}$ & 126 & 23 \\
\hline İç Anadolu & 93 & 16,9 & $1941-1950$ & 207 & 37,8 & Avukat & 56 & 10,3 & $\mathrm{MHP}+\mathrm{BBP}$ & 131 & 23,9 \\
\hline Karadeniz & 76 & 13,8 & $1951-1960$ & 210 & 38,3 & Mühendis & 82 & 15 & $\mathrm{SP}+\mathrm{AKP}$ & 106 & 19,4 \\
\hline Doğu Anadolu & 57 & 10,5 & 1961-1969 & 55 & 10 & İş Adamı & 62 & 11,1 & BAĞIMSIZ & 28 & 5,1 \\
\hline \multirow[t]{2}{*}{ Güney D. An. } & 54 & 9,8 & Toplam & 548 & 100 & \multirow{2}{*}{$\begin{array}{l}\text { Hakim-Saveı } \\
\text { Mali Müşavir }\end{array}$} & \multirow{2}{*}{$\begin{array}{r}4 \\
15\end{array}$} & 0,7 & Toplam & 548 & 100 \\
\hline & 548 & 100 & $\begin{array}{l}\text { M.nin Ö̆r. } \\
\text { Drm }\end{array}$ & $\mathbf{N}$ & & & & 2,7 & & & \\
\hline M.nin Cinsiyeti & $\mathbf{N}$ & $\%$ & Yüksek & 500 & 91,3 & Sanayici & 22 & 4,1 & & & \\
\hline Erkek & 526 & 95,9 & Lise & 31 & 5,6 & Çiftçi & 22 & 4,1 & & & \\
\hline Kadin & 22 & 4,1 & Ortaokul & 11 & 2 & İş̧i-Sendikacı & 5 & 0,9 & & & \\
\hline Toplam & 548 & 100 & İlkokul & 6 & 1,1 & Özel Sek.Yön & 48 & 8,8 & & & \\
\hline & & & Toplam & 548 & 100 & $\begin{array}{l}\text { Memur } \\
\text { Toplam }\end{array}$ & $\begin{array}{r}48 \\
548\end{array}$ & $\begin{array}{r}8,8 \\
100\end{array}$ & & & \\
\hline
\end{tabular}




\section{21. DÖNEMDE GENEL YASAMA ETKINNLİ̛̆̃}

Bu başlık altında yasa önerileri kendi içlerinde bir ayrıma tabi tutulmaksızın, genel yasama etkinliği incelenecektir. Öncelikle yasama etkinliğine milletvekillerinin katılımına bakıldığında, 548 milletvekilinden 27 'sinin yasa yapımı sürecinde hiçbir öneriye imza atmadığı görülmektedir. Başka bir ifade ile Meclis'in yaklaşık \%5'i yasama etkinliğine katılmamıştır (Bkz.Tablo.3). İllere göre yasama etkinliğine katılmayan milletvekillerinin dağılımına bakıldığında İstanbul 8 milletvekili ile ilk, İzmir 4 milletvekili ile ikinci sirada gelmektedir. Oransal olarak bakıldığında ise yine ilk sıray $\% 29.6$ ile İstanbul, ikinci sırayı ise yine \%14.9 ile İzmir almaktadır. Bölgesel olarak yasama etkinliğine katılmayan milletvekillerinin dağılımına bakıldığında Marmara Bölgesinin ilk sırayı aldığı, bu bölgeyi Ege ve İç Anadolu Bölgelerinin izlediği görülmektedir. Doğu Anadolu Bölgesi milletvekilleri içinde ise yasama etkinliklerine katılmayan milletvekili bulunmamaktadır. Cinsiyet açısından bakıldığında kadın milletvekillerinin tamamının yasama etkinliğine katıldıkları, yasama etkinliğine katılmayan milletvekillerinin tamamının erkek olduğu görülmektedir.

Partiler açısından yasama etkinliğine katılmamakta öncelikle Meclis'in son resmi dağılımı dikkate alındığında ANAP, DSP, DYP'nin 5'er milletvekili ile ilk sirada yer aldıkları, bunu 4'er milletvekili ile MHP ve YTP'nin izlediği görülmektedir. Illginç bir bulgu iktidar partilerinin milletvekilleri arasında yasama etkinliğine katılmama oranının yüksek olmasıdır. Toplam 27 milletvekili içinden 17 kişi iktidar partilerinden gelmektedir. Meclis'in açılışındaki parti dağılımı açısından incelendiğinde, bu sayı (ANAP+YP, DSP+YTP+CHP+ÖDP) 21 'e yükselmektedir. Kısaca yasama etkinliğine katılım noktasında "muhalefet partileri" daha aktif bir görünüm sergilemektedirler. Yasama etkinliğine katılmama açısından DSP ve ondan ayrilan milletvekilinin katılmayan üyeler içinde \%40 gibi bir oranı oluşturmaları dikkat çekicidir.

Milletvekillerinin doğum tarihleri açısından katılmaya bakıldığında; en aktif yaş grubunun 1951-1960 doğumlular olduğu görülmektedir. Rakamsal olarak 19411950 doğumlular, oransal olarak da 1921-1930 yaş grubunun daha az katılım gösterdikleri belirtilebilir.

21. dönem milletvekili profili de, genel olarak yüksek ögrenim görmüş milletvekillerinin ağırlıta olduğu bir dağılıma sahiptir. 548 milletvekilinin 500'ü yüksek ögrrenim görmüștür. Bunun bir sonucu olarak yüksek öğrenim mezunları arasında yasama etkinliğine katılmama diğer ögrenim gruplarına göre daha yüksektir. Oransal olarak yasama etkinliğine katılmama davranışında lise mezunları biraz daha öne geçmektedir. Buna karşılık ortaokul ve ilkokul mezunları yasama etkinliklerine katılmışlardır.

Dikkat çekici bir bulgu da, uğraş alanlarına göre katılım göstermeyen milletvekilleri dağılımında görülmektedir. 27 milletvekili içinde öğretim üyeleri ve bürokratlar toplam 14 kişi ile ilk sırada gelmektedir. Buna karşıllk hakim-savcı, muhasebeci-mali müşavirler, ve sendikacılar aktif katılım gösteren uğraş alanları olarak öne çıkmaktadırlar.

Tablo.3: Yasama Etkinliğine Katılmayan Milletvekillerinin Ỉl, Bölge, Cinsiyet, Öğrenim Durumu, Uğraş Alanı, Parti, Doğum Tarihlerine Göre Dağılımı

\begin{tabular}{|c|c|c|c|c|c|c|c|c|c|c|c|}
\hline M.nin İli & $\mathbf{N}$ & $\%$ & M.nin Bölgesi & $\mathbf{N}$ & $\%$ & M.nin Ugraş Alanı & $\mathbf{N}$ & $\%$ & M.nin Partisi & $\mathbf{N}$ & $\%$ \\
\hline Antalya & 1 & 3.7 & Marmara & 11 & 40.8 & Ögretim Üyesi & 6 & 22.2 & ANAP+YP & 6 & 22,2 \\
\hline Balıkesir & 1 & 3.7 & Ege & 5 & 18.5 & Bürokrat & 8 & 29.7 & $\mathrm{DSP}+\mathrm{CHP}+\mathrm{YTP}+\mathrm{ÖDP}$ & 11 & 40,7 \\
\hline Bursa & 1 & 3.7 & Akdeniz & 2 & 7.4 & $\begin{array}{c}\text { Sağlık Gru. Serbest } \\
\text { Mes. }\end{array}$ & 0 & 0 & $\mathrm{MHP}+\mathrm{BBP}$ & 4 & 15 \\
\hline Gaziantep & 1 & 3.7 & İ ç Anadolu & 4 & 14.8 & Avukat & 2 & 7.4 & DYP & 5 & 18.4 \\
\hline İstanbul & 8 & 29,6 & Karadeniz & 2 & 7.4 & Mühendis & 3 & 11.1 & $S P+A K P$ & 0 & 0 \\
\hline İzmir & 4 & 14,9 & Dogu Anadolu & 0 & 0 & İş Adamı & 1 & 3.7 & BAĞIMSIZ & 1 & 3.7 \\
\hline Kayseri & 1 & 3.7 & Güney D. An. & 3 & 11.1 & Hakim-Savcı & 0 & 0 & Toplam & 27 & 100 \\
\hline Konya & 1 & 3.7 & Toplam & 27 & 100 & Mali Müşavir & 0 & 0 & M.nin Doğum Tarihi & $\mathbf{N}$ & $\%$ \\
\hline Kütahya & 1 & 3.7 & M.nin Cinsiyeti & $\mathbf{N}$ & $\%$ & Sanayici & 1 & 3.7 & $1911-1920$ & 0 & 0 \\
\hline Rize & 1 & 3.7 & Erkek & 27 & 100 & Çiftçi & 3 & 11.1 & $1921-1930$ & 2 & 7.4 \\
\hline Sinop & 1 & 3.7 & Kadin & 0 & 0 & İşçi-Sendikacı & 0 & 0 & $1931-1940$ & 7 & 25.9 \\
\hline Sivas & 1 & 3.7 & Toplam & 27 & 100 & Özel Sektör Yön. & 2 & 7.4 & $1941-1950$ & 14 & 51.9 \\
\hline Tekirdağ & 1 & 3.7 & M.nin Ögr.Drm & $\mathbf{N}$ & $\%$ & Memur & 1 & 3.7 & $1951-1960$ & 3 & 11.1 \\
\hline Sanilurfa & 2 & 7,4 & Yüksek & 25 & 92.5 & & & & $1961-1969$ & 1 & 3.7 \\
\hline Karaman & 1 & 3.7 & Lise & 2 & 7.5 & Toplam & 27 & 100 & Toplam & 27 & 100 \\
\hline Osmaniye & 1 & 3.7 & $\begin{array}{l}\text { Ortaokul } \\
\text { İlkokul }\end{array}$ & $\begin{array}{l}0 \\
0\end{array}$ & $\begin{array}{l}0 \\
0\end{array}$ & & & & & & \\
\hline Toplam & 27 & 100 & Toplam & 27 & 0 & & & & & & \\
\hline
\end{tabular}


Genel Yasama etkinliğine katılım, 8 grup altında Tablo 4'de gösterilmektedir. Buna göre en fazla etkinlik 6-10 yasa önerisi düzeyinde gerçekleşmiştir. Hiç imza vermeyenler ve 1-5 öneriye imza veren milletvekillerinin toplamı 171 kişidir. Başka bir ifade ile milletvekillerininin \%31'inin pasif katılım sergiledikleri belirtilebilir. Meclis'in genel etkinliğinin 1-15 öneri arasında yoğunlaştığı görülmektedir (Toplam 416 milletvekili). İllere göre genel yasama etkinliğine bakıldığında büyük kentlerden gelen milletvekillerinin çok aktif olmadıkları görülmektedir. Ankara milletvekillerinin tamamı yasama etkinliklerine katılmış, ancak bunların üçte birinden fazlası ( 10 milletvekili) yalnızca bir öneriye imza atmıştır. 16'dan fazla öneriye imza atan Ankaralı milletvekili sayısı yalnızca 4'tür. İstanbul'un 8 milletvekili hiç yasama etkinliğine katılmazken, 19'u yalnızca bir öneriye imza atmıştır (İstanbul milletvekillerinin yarıya yakını). 16'dan fazla öneriye imza atan milletvekili sayısı ise 4 'tür. İzmir'de 4 yasama etkinliğine katılmayan, 4 tane de 1 öneriye imza atan milletvekili vardır. 16'dan fazla öneriye imza atan milletvekili sayısı ise yalnızca ikidir.

Tablo.4: Yasama Etkinlik Frekansı

\begin{tabular}{crr}
\hline Yasama Etkinliği Sayısı & \multicolumn{1}{c}{$\mathbf{N}$} & \multicolumn{1}{c}{$\%$} \\
\hline 0 & 27 & 4,9 \\
$1-5$ & 144 & 26.3 \\
$6-10$ & 170 & 31 \\
$11-15$ & 102 & 18.6 \\
$16-20$ & 52 & 9,5 \\
$21-25$ & 40 & 7.3 \\
$26-35$ & 8 & 1.5 \\
$36-50$ & 5 & 0.9 \\
Toplam & 548 & 100 \\
\hline
\end{tabular}

Buna karşılık küçük iller, büyük kentlere göre daha aktif bir tablo sergilemektedirler. Örneğin 36-50 arası öneriye imza atan 5 milletvekili içinde Mersin dışında büyük kentlerden milletvekili bulunmamaktadır. 26-35 yasa önerisi arasında imza atan 10 milletvekilinden yalnızca 1'i Ankara milletvekilidir. Dolayısıyla kent büyüklüğü ile milletvekili etkinliği arasında bir ilişkinin varlığından söz etmek güç görünmektedir.

Bölgeler açısından genel yasama etkinliğine bakıldığında ağırlığın yine $6-10$ arasında imzada bulunduğu görülmektedir (Tablo.5). Ancak burada Marmara, Ege ve Karadeniz Bölgeleri daha önde gelmektedir. Buna karşılık 1-5 arasında öneride imzası bulunan milletvekilleri içinde Doğu ve Güneydoğu Bölgeleri milletvekilleri oransal olarak öne çıkmaktadırlar. Bölgelere göre dağılımda bir tek Güneydoğu Bölgesi milletvekillerinin 26 üzerinde öneri sunma kategorilerinde imzaları bulunmamakta, diğer bölgelerin belli bir düzeyde yer aldıkları görülmektedir.Doğu Anadolu Bölgesi'nin gösterdiği dağılım, özellikle 16'dan yukarı kategorilerde dikkat çekicidir.

Partiler açısından genel etkinlik değerlendirmesi yapılırken belirtildiği gibi, birbirlerinden ayrılan partilere üye milletvekilleri davranışları bir arada değerlendirilmiştir (Tablo.6). Bu çerçevede ANAP+YP, $\mathrm{DSP}+\mathrm{YTP}+\mathrm{CHP}+\mathrm{ODP} ; \mathrm{SP}+\mathrm{AKP}$ ile $\mathrm{MHP}+\mathrm{BBP}$ ayrı ayrı değerlendirilmişler; DYP ve bağımsızlar için ise son milletvekili sayıları esas alınmıştır. Buna göre; etkinlik göstermeyen partiler içinde ilk sırayı iktidarın büyük ortağı DSP+YTP+CHP+ÖDP grubu yani Meclis'e DSP çatısı altında giren milletvekilleri almaktadır. $\mathrm{Bu}$ grubun \%8.7'si Meclis'in yasama etkinliğine hiç katılmamıştır (Partilerle ilgili degerlendirme yapılırken, çalışmanın kapsam olarak yalnızca 21. Dönem etkinliklerini içermesi, dolayısıyla karşılaştırmalı bir yöntem izlenmemiş olması nedeniyle; Meclisi oluşturan sol ve sağ kanat partilerin milletvekili davranıșları yalnızca incelenen döneme özgü belirlemeler olarak kabul edilmeli, partilerin temel eğilimi olarak genelleştirilmemelidir. Böyle bir genelleme ancak bir kaç dönem etkinliğin karşılaştırmalı olarak analizi ile mümkündür).

TBMM üyeleri ağırlıklı olarak 40-60 yaş grubu içinde yoğunlaşmışlardır. Meclis'in 21. dönemde bu yaş grubuna giren üyelerinin oranı \%76.1'dir. Dolayısıyla yasama etkinliğine ağırlığını koyan da bu yaş grubu milletvekilleri olmuştur. Bu grubu daha yaşlı

(60-70) ve daha genç (30-40) yaş grupları izlemektedir. Her bir yaş grubunun kendi içindeki dağılımına bakıldığında sayıca az olmalarına karşın genç milletvekillerinin aktif bir katılım sergiledikleri söylenebilir (Tablo.7).

Tablo.5: Milletvekilinin Bölgesi/Yasama Etkinliği

\begin{tabular}{|c|c|c|c|c|c|c|c|c|c|c|c|c|c|c|c|c|c|c|}
\hline & \multicolumn{2}{|c|}{0} & \multicolumn{2}{|c|}{ 1-5 } & \multicolumn{2}{|c|}{$6-10$} & \multicolumn{2}{|c|}{$11-15$} & \multicolumn{2}{|c|}{$16-20$} & \multicolumn{2}{|c|}{$21-25$} & \multicolumn{2}{|c|}{$26-35$} & \multicolumn{2}{|c|}{$36-50$} & \multirow[t]{2}{*}{$\mathbf{T}$} & \multirow[t]{2}{*}{ T \% } \\
\hline & $\mathbf{N}$ & $\%$ & $\mathbf{N}$ & $\%$ & $\mathbf{N}$ & $\%$ & $\mathbf{N}$ & $\%$ & $\mathbf{N}$ & $\%$ & $\mathbf{N}$ & $\%$ & $\mathbf{N}$ & $\%$ & $\mathbf{N}$ & $\%$ & & \\
\hline Marmara & 11 & 8,5 & 35 & 27,1 & 47 & 36,4 & 21 & 16,3 & 5 & 3,9 & 7 & 5,4 & 2 & 1,6 & 1 & 0,8 & 129 & 100 \\
\hline Ege & 5 & 7 & 13 & 18,3 & 29 & 40,9 & 14 & 19,7 & 3 & 4,2 & 6 & 8,5 & 1 & 1,4 & 0 & 0 & 71 & 100 \\
\hline Akdeniz & 2 & 2,9 & 13 & 19,1 & 21 & 30,9 & 13 & 19,1 & 11 & 16,2 & 5 & 7,4 & 1 & 1,5 & 2 & 2,9 & 68 & 100 \\
\hline İç Anadolu & 4 & 4,3 & 26 & 27,9 & 22 & 23,7 & 20 & 21,5 & 13 & 13,9 & 7 & 7,6 & 1 & 1,1 & 0 & 0 & 93 & 100 \\
\hline Karadeniz & 2 & 2,6 & 19 & 25 & 26 & 34,3 & 13 & 17,1 & 9 & 11,8 & 5 & 6,6 & 2 & 2,6 & 0 & 0 & 76 & 100 \\
\hline Doğu Anadolu & 0 & 0 & 18 & 31,5 & 11 & 19,3 & 12 & 21,1 & 6 & 10,5 & 8 & 14 & 1 & 1,8 & 1 & 1,8 & 57. & 100 \\
\hline Güney D. An. & 3 & 5,5 & $20 、$ & 37,1 & 14 & 25,9 & 9 & 16,7 & 5 & 9,3 & 3 & 5,5 & 0 & 0 & 0 & 0 & 54 & 100 \\
\hline
\end{tabular}


Öğrenim durumu açısından da TBMM ağırlıklı olarak yüksek öğrenim görmüş bir milletvekili profiline sahiptir. 500 milletvekili bu şekilde yüksek öğrenim görmüşlerdir. Dolayısıyla yüksek öğrenim gören milletvekilleri her kategoride katılım göstermişlerdir. Ancak yüksek öğrenim gören milletvekillerinin $\% 5$ 'i, lise mezunu milletvekillerinin \%6,5'ü yasama etkinliğine katılmamışlardır (Tablo.8). Buna karşıllık ortaokul ve ilkokul mezunları içinde yasama etkinliğine katılmayan milletvekili yoktur. Ancak bu milletvekillerinin katılım yoğunlukları yüksek öğrenim ve lise mezunlarının daha gerisindedir.

21. dönem milletvekili profili içinde uğraş alanları açıdan en kalabalık grubu 82 kişi ile mühendis-mimar- teknik uzman grubu oluşturmaktadir. Bu grubu 74 kişi ile bürokratlar, 64 kişi ile öğretim üyeleri, 62 kişi ile işadamı-tüccar grubu izlemektedir. İşçi ve sendika temsilcileri 5 kişi ile, hakim ve savcilar 4 kişi ile en küçük grupları oluşturmaktadırlar. Daha farklı bir değerlendirme ile Meclis'te 190 kişinin devlet kurumlarında çalış̧ıkları, 199 kişinin uzmanlığa dayalı serbest meslek ile uğraştığı, 132 kişinin özel sektörü temsil ettiği, 5 kişinin iş̧̧i kesiminden olduğu, 22 kişinin de çiftçilikle uğraştığ 1 belirtilebilir.Bu dağılım 21. Dönemde Meclis'te serbest meslek-bürokrasi grubunun uğraş alanına ait çıkarlar açısından daha baskın bir konumda bulunduğunu göstermektedir. Çeşitli özel sektör gruplarının Meclis içindeki ağırlığı da küçümsenmeyecek düzeydedir (Tablo.9).

Tablo.6: Milletvekilinin Partisi/Yasama Etkinliği

\begin{tabular}{|c|c|c|c|c|c|c|c|c|c|c|c|c|c|c|c|c|c|c|}
\hline & \multicolumn{2}{|c|}{0} & \multicolumn{2}{|c|}{$1-5$} & \multicolumn{2}{|c|}{$6-10$} & \multicolumn{2}{|c|}{11.15} & \multicolumn{2}{|c|}{$16-20$} & \multicolumn{2}{|c|}{$21-25$} & \multicolumn{2}{|c|}{$26-35$} & \multicolumn{2}{|c|}{$36-50$} & \multirow[t]{2}{*}{$\mathbf{T}$} & \multirow[t]{2}{*}{$\mathbf{T} \%$} \\
\hline & $\mathbf{N}$ & $\%$ & $\mathbf{N}$ & $\%$ & $\mathbf{N}$ & $\%$ & $\mathbf{N}$ & $\%$ & $\mathbf{N}$ & $\%$ & $\mathbf{N}$ & $\%$ & $\mathbf{N}$ & $\%$ & $\mathbf{N}$ & $\%$ & & \\
\hline ANAP+YP & 6 & 8 & 36 & 48 & 22 & 29,4 & 8 & 10,7 & 1 & 1,3 & 2 & 2,6 & 0 & 0 & 0 & 0 & 75 & 100 \\
\hline $\begin{array}{l}\text { DSP+YTP+ } \\
\text { CHP+ÖDP }\end{array}$ & 11 & 8,7 & 44 & 35 & 57 & 45,2 & 12 & 9,5 & 2 & 1,6 & 0 & 0 & 0 & 0 & 0 & 0 & 126 & 100 \\
\hline DYP & 5 & 6,1 & 24 & 29,3 & 34 & 41,4 & 12 & 14,6 & 3 & 3,7 & 1 & 1,2 & 0 & 0 & 3 & 3,7 & 82 & 100 \\
\hline $\mathrm{MHP}+\mathrm{BBP}$ & 4 & 3,1 & 21 & 16 & 32 & 24,5 & 38 & 29 & 21 & 16 & 11 & 8,4 & 2 & 1,5 & 2 & 1,5 & 131 & 100 \\
\hline $\mathrm{SP}+\mathrm{AKP}$ & 0 & 0 & 7 & 6,6 & 20 & 18,8 & 28 & 26,5 & 23 & 21,7 & 23 & 21,7 & 5 & 4,7 & 0 & 0 & 106 & 100 \\
\hline BAĞIMSIZ & 1 & 3,6 & 13 & 46,4 & 6 & 21,4 & 4 & 14,2 & 1 & 3,6 & 2 & 7,2 & 1 & 3,6 & 0 & 0 & 28 & 100 \\
\hline
\end{tabular}

Tablo.7: Milletvekilinin Doğum Tarihi/Yasama Etkinliği

\begin{tabular}{|c|c|c|c|c|c|c|c|c|c|c|c|c|c|c|c|c|c|c|}
\hline & \multicolumn{2}{|c|}{0} & \multicolumn{2}{|c|}{$1-5$} & \multicolumn{2}{|c|}{ 6-10 } & \multicolumn{2}{|c|}{ 11-15 } & \multicolumn{2}{|c|}{$16-20$} & \multicolumn{2}{|c|}{$21-25$} & \multicolumn{2}{|c|}{$26-35$} & \multicolumn{2}{|c|}{$36-50$} & \multirow[t]{2}{*}{$T$} & \multirow[t]{2}{*}{$\mathrm{T} \%$} \\
\hline & $\mathbf{N}$ & $\%$ & $\mathbf{N}$ & $\%$ & $\mathbf{N}$ & $\%$ & $\mathbf{N}$ & $\%$ & $\mathbf{N}$ & $\%$ & $\mathbf{N}$ & $\%$ & $\mathbf{N}$ & $\%$ & $\mathbf{N}$ & $\%$ & & \\
\hline $1911-1920$ & 0 & 0 & 1 & 50 & 1 & 50 & 0 & 0 & 0 & 0 & 0 & 0 & 0 & 0 & 0 & 0 & 2 & 100 \\
\hline $1921-1930$ & 2 & 14,2 & 7 & 50 & 2 & 14,2 & 2 & 14,2 & 1 & 7,2 & 0 & 0 & 0 & 0 & 0 & 0 & 14 & 100 \\
\hline $1931-1940$ & 7 & 11,2 & 16 & 25,6 & 21 & 33,6 & 12 & 19,2 & 1 & 1,6 & 2 & 3,2 & 0 & 0 & 1 & 1,6 & 60 & 100 \\
\hline $1941-1950$ & 14 & 6,8 & 58 & 28 & 65 & 31,4 & 25 & 12,1 & 18 & 8,7 & 20 & 9,7 & 3 & 1,4 & 4 & 1,9 & 207 & 100 \\
\hline $1951-1960$ & 3 & 1,4 & 50 & 23,5 & 60 & 28,5 & 50 & 23,5 & 25 & 11,5 & 15 & 7 & 3 & 1,4 & 0 & 0 & 210 & 100 \\
\hline $1961-1969$ & 1 & 1,8 & 12 & 21,6 & 21 & 37,5 & 12 & 21,6 & 3 & 5,4 & 2 & 3,6 & 2 & 3,6 & 0 & 0 & 55 & 100 \\
\hline
\end{tabular}

Tablo.8: Milletvekilinin Öğrenim Durumu/Yasama Etkinliği

\begin{tabular}{|c|c|c|c|c|c|c|c|c|c|c|c|c|c|c|c|c|c|c|}
\hline & \multicolumn{2}{|c|}{0} & \multicolumn{2}{|c|}{$1-5$} & \multicolumn{2}{|c|}{$6-10$} & \multicolumn{2}{|c|}{ 11-15 } & \multicolumn{2}{|c|}{$16-20$} & \multicolumn{2}{|c|}{$21-25$} & \multicolumn{2}{|c|}{$26-35$} & \multicolumn{2}{|c|}{$36-50$} & \multirow[t]{2}{*}{$\mathbf{T}$} & \multirow[t]{2}{*}{$\mathrm{T} \%$} \\
\hline & $\mathbf{N}$ & $\%$ & $\mathbf{N}$ & $\%$ & $\mathbf{N}$ & $\%$ & $\mathbf{N}$ & $\%$ & $\mathbf{N}$ & $\%$ & $\mathbf{N}$ & $\%$ & $\mathbf{N}$ & $\%$ & $\mathbf{N}$ & $\%$ & & \\
\hline Yüksek & 25 & 5 & 129 & 25,8 & 150 & 30 & 96 & 19,2 & 48 & 9,6 & 39 & 7,8 & 8 & 1,6 & 5 & 1 & 500 & 100 \\
\hline Lise & 2 & 6,5 & 9 & 29,1 & 14 & 45,2 & 3 & 9,6 & 2 & 6,4 & 1 & 3,2 & 0 & 0 & 0 & 0 & 31 & 100 \\
\hline Ortaokul & 0 & 0 & 3 & 27,3 & 4 & 36,3 & 2 & 18,2 & 2 & 18,2 & 0 & 0 & 0 & 0 & 0 & 0 & 11 & 100 \\
\hline İlkokul & 0 & 0 & 3 & 50 & 2 & 33,3 & 1 & 16,7 & 0 & 0 & 0 & 0 & 0 & 0 & 0 & 0 & 6 & 100 \\
\hline
\end{tabular}

Tablo.9: Milletvekilinin Uğraş Alanı/Yasama Etkinliği

\begin{tabular}{|c|c|c|c|c|c|c|c|c|c|c|c|c|c|c|c|c|c|c|}
\hline & \multicolumn{2}{|c|}{0} & \multicolumn{2}{|c|}{$1-5$} & \multicolumn{2}{|c|}{$6-10$} & \multicolumn{2}{|c|}{ 11-15 } & \multicolumn{2}{|c|}{$16-20$} & \multicolumn{2}{|c|}{$21-25$} & \multicolumn{2}{|c|}{$26-35$} & \multicolumn{2}{|c|}{$36-50$} & \multirow[t]{2}{*}{$\mathbf{T}$} & \multirow[t]{2}{*}{$\mathbf{T} \%$} \\
\hline & $\mathbf{N}$ & $\%$ & $\mathbf{N}$ & $\%$ & $\mathbf{N}$ & $\%$ & $\mathbf{N}$ & $\%$ & $\mathbf{N}$ & $\%$ & $\mathbf{N}$ & $\%$ & $\mathbf{N}$ & $\%$ & $\mathbf{N}$ & $\%$ & & \\
\hline Ögretim Üyesi & 6 & 9,4 & 13 & 20,3 & 18 & 28,1 & 17 & 26,6 & 5 & 7,8 & 5 & 7,8 & 0 & 0 & 0 & 0 & 64 & 100 \\
\hline Bürokrat & 8 & 10,9 & 23 & 31,1 & 17 & 22,9 & 12 & 16,2 & 2 & 2,7 & 8 & 10,8 & 2 & 2,7 & 2 & 2,7 & 74 & 100 \\
\hline Sglk Gr. Ser Mes. & 0 & 0 & 11 & 23,9 & 18 & 39,1 & 7 & 15,2 & 4 & 8,7 & 4 & 8,7 & 2 & 4,4 & 0 & 0 & 46 & 100 \\
\hline Avukat & 2 & 3,6 & 15 & 26,8 & 12 & 21,4 & 11 & 19,6 & 9 & 16,1 & 6 & 10,7 & 0 & 0 & 1 & 1,8 & 56 & 100 \\
\hline Mühendis & 3 & 3,6 & 24 & 29,3 & 23 & 28,1 & 19 & 23,2 & 10 & 12,2 & 2 & 2,4 & 1 & 1,2 & 0 & 0 & 82 & 100 \\
\hline İș Adamı & 1 & 1,6 & 15 & 24,2 & 25 & 40,3 & 11 & 17,7 & 5 & 8,1 & 5 & 8,1 & 0 & 0 & 0 & 0 & 62 & 100 \\
\hline Hakim-Savc1 & 0 & 0 & 1 & 25 & 1 & 25 & 1 & 25 & 0 & 0 & 0 & 0 & 0 & 0 & 1 & 25 & 4 & 100 \\
\hline Mali Müşavir & 0 & 0 & 3 & 20 & 7 & 46,7 & 1 & 6,7 & 2 & 13,2 & 1 & 6,7 & 1 & 6,7 & 0 & 0 & 15 & 100 \\
\hline Sanayici & 1 & 4,5 & 6 & 27,4 & 8 & 36,3 & 4 & 18,3 & 1 & 4,5 & 2 & 9 & 0 & 0 & 0 & 0 & 22 & 100 \\
\hline Çiftçi & 3 & 13,6 & 9 & 40,9 & 6 & 27,3 & 2 & 9,1 & 2 & 9,1 & 0 & 0 & 0 & 0 & 0 & 0 & 22 & 100 \\
\hline İşçi-Sendikacı & 0 & 0 & 2 & 40 & 1 & 20 & 1 & 20 & 0 & 0 & 1 & 20 & 0 & 0 & 0 & 0 & 5 & 100 \\
\hline Özel Sekt. Yön. & 2 & 4,2 & 17 & 35,4 & 19 & 39,6 & 6 & 12,5 & 3 & 6,3 & 1 & 2 & 0 & 0 & 0 & 0 & 48 & 100 \\
\hline Memur-Ögretm. & 1 & 2,1 & 5 & 10,4 & 15 & 31,2 & 10 & 20,8 & 9 & 18,8 & 5 & 10,4 & 2 & 4,2 & 1 & 2,1 & 48 & 100 \\
\hline
\end{tabular}


Genel etkinlik açısından bu dağılıma bakıldığında sayısal olarak daha az olmalarına karşı çiftçilerin \%13,6 oranında yasama etkinlikliğine katılmamaları dikkat çekicidir. Sayısal azlıklarına rağmen işçilerle, hakim ve savcıların aktif bir tutum sergiledikleri söylenebilir. Bürokratların yaklaşık \%41'inin hiç imzası olmayanlarla 1-5 kategorisinde olması dikkat çekicidir. Bu bürokratların yasama faaliyetlerindeki etkinlikleri yüksek olmakla birlikte, grup kendi içerisinde önemli oranda bir pasif milletvekili sayısını barındırmaktadır. Öğretim üyeleri çok aktif olmamakla birlikte dengeli bir dağılım göstermektedirler. Serbest meslek grubu (sağlık, avukat, mühendisler, mali müşavirler) en aktif uğraş alanı grubu olarak değerlendirilebilir. Bu grup hemen her kategoride katılımda bulunduğu gibi, katılmama konusunda da en düşük orana sahip grubu oluşturmaktadirlar. Bu gurubu memur ve öğretmenler izlemekte, özel sektörü temsil eden gruplar ise (sanayici, tüccar, özel sektör yöneticileri) belirli bir ağırlığa sahip bulunmaktadırlar. Dolayısıyla genel yasama etkinliği açısından, sayısal açıdan kalabalık olan bürokrat ve öğretim üyelerinin oransal açıdan serbest meslek grubu, memur-ögretmen ve özel sektör temsilcilerinin daha gerisinde kaldıkları söylenebilir.

\section{ULUSAL DÜZENLEMELER VE YASAMA ETKINLIIĞi}

$\mathrm{Bu}$ başlık altında milletvekilinin uğraş alanı ve temsil ettiği il ve bölgeyle ilgili olmayan, yine başka bir özel durum ve çıkarı desteklemeyen yasa önerileri incelenmektedir (Bu grup altında toplanan yasa önerilerine; RTÜK'ün basın kartlı asgari ve zorunlu personel sayısını belirleme yetkisinin bu kurumdan alınarak, kanun tarafından doğrudan belirlenmesini içeren ve bu amaçla 3984 sayılı yasada ve Basın Yasasında değişiklik getiren 113 sayılı yasa önerisi; yine Türk Ceza Kanunun'da düzenlenen para cezalarının günün şartlarına göre yeniden belirlenmesini içeren 181 sayılı yasa önerisi örnek olarak verilebilir). Çalışmada bu kapsamda toplam 247 yasa önerisi değerlendirilmiştir.
Ulusal düzenlemeye dönük yasa önerisine imza atmayan milletvekillerine il düzeyinde baktığımızda Gümüşhane, Kars ve Kilis milletvekillerinin (toplam 7 kişi) hiç birinin genel düzenlemeye yönelik yasa önerisi vermedikleri, buna karşılık Adıyaman, Ağrı, Aydın, Bingöl, Bitlis, Bolu,Burdur, Edirne, Erzurum, Hakkari, Hatay, Muğla, Nevşehir, Tunceli, Batman, Bartın, Ardahan, Iğdır ve Karabük milletvekillerinin tamamının genel düzenlemeye ilişkin yasa önerilerine imza verdikleri görülmektedir. Dikkat edilirse bu açıdan küçük kentlerden gelen milletvekilleri ile, büyük kent milletvekilleri arasında bir ayrım söz konusu değildir. Hatta küçük kent milletvekillerinin genele dönük yasa önerileri konusunda daha aktif bir tutum sergiledikleri söylenebilir. Örneğin 68 İstanbul milletvekillerinden35'i (\%51,4), 24 İzmir milletvekillerinden $\quad 8$ 'i $\quad(\% 33,3), \quad 28 \quad$ Ankara milletvekilinden 7'si (\%25), genel yasa önerisine imza atmamışlardır. Adana, Bursa, Eskişehir, Gaziantep, Kayseri, Kocaeli, Konya gibi büyük kentlerde ağırlık genele dönük yasa önerilerindedir. Ancak bu illerde hiç öneri vermeyen milletvekilleri bulunmaktadır. Antalya'da genel yasa önerisine imza atmayan milletvekili sayısı il milletvekillerinin yarısıdır (6 kişi \%50).

Bölgeler açısından dağılıma bakıldığında sırasıyla Marmara, İç Anadolu, Karadeniz ve Güneydoğu Anadolu Bölgeleri milletvekillerinin ulusal düzenlemelere dönük yasa önerilerine daha az katkı yaptıkları, en fazla katkının ise Ege Bölgesinden geldiği görülmektedir (Tablo.10). Hiç vermeyenlerle bir öneriye imza atanların oranı Marmara Bölgesinde \%59'u, İç Anadolu Bölgesinde \%60'1, Güneydoğuda \%70'i bulmaktadır. Buna karşılık Dogu Anadolu ve Akdeniz milletvekilleri içinde 1 öneriye imza atan milletvekilleri çoğunluktadır.

Genele dönük düzenlemeler konusunda Ege Bölgesi daha aktif bir dağılım göstermektedir. Genel olarak yoğunlaşma 1 öneride kalmaktadır. Meclis'te en kalabalık grubu oluşturan Marmara Bölgesi'nde 10'dan fazla öneri sunan bir milletvekili bulunmaktadır.

Tablo.10: Milletvekilinin Bölgesi/Yasama Etkinliği

\begin{tabular}{|c|c|c|c|c|c|c|c|c|c|c|c|c|c|c|}
\hline & \multicolumn{2}{|c|}{0} & \multicolumn{2}{|c|}{$1-3$} & \multicolumn{2}{|c|}{$4-6$} & \multicolumn{2}{|c|}{ 7-10 } & \multicolumn{2}{|c|}{ 11-19 } & \multicolumn{2}{|c|}{$20-30$} & \multirow[t]{2}{*}{$\mathbf{T}$} & \multirow[t]{2}{*}{$\mathrm{T} \%$} \\
\hline & $\mathbf{N}$ & $\%$ & $\mathbf{N}$ & $\%$ & $\mathbf{N}$ & $\%$ & $\mathbf{N}$ & $\%$ & $\mathbf{N}$ & $\%$ & $\mathbf{N}$ & $\%$ & & \\
\hline Marmara & 43 & 33,3 & 63 & 48,9 & 19 & 14,7 & 4 & 3,1 & 0 & 0 & 0 & 0 & 129 & 100 \\
\hline Ege & 15 & 21,1 & 33 & 46,5 & 21 & 29,6 & 1 & 1,4 & 1 & 1,4 & 0 & 0 & 71 & 100 \\
\hline Akdeniz & 21 & 30,9 & 37 & 54,4 & 9 & 13,2 & 1 & 1,5 & 0 & 0 & 0 & 0 & 68 & 100 \\
\hline İç Anadolu & 32 & 34,4 & 45 & 48,4 & 15 & 16,1 & 0 & 0 & 0 & 0 & 1 & 1,1 & 93 & 100 \\
\hline Karadeniz & 26 & 34,2 & 38 & 50 & 10 & 13,2 & 2 & 2,6 & 0 & 0 & 0 & 0 & 76 & 100 \\
\hline Doğu Anadolu & 15 & 26,3 & 38 & 66,7 & 2 & 3,5 & 0 & 0 & 2 & 3,5 & 0 & 0 & 57 & 100 \\
\hline G.Doğu Anadolu & 18 & 33,3 & 34 & 63 & 2 & 3,7 & 0 & 0 & 0 & 0 & 0 & 0 & 54 & 100 \\
\hline
\end{tabular}


Partiler açısından dağılıma bakıldığında genel düzenlemelere ilgisizlik açısından DYP $(37,8)$, MHP+BBP $(37,4)$ ve ANAP+YP $(29,3)^{\prime}$ nin ilk üç sırada geldikleri görülmektedir (Tablo.11). Ancak MHP+BBP ve DYP dışındaki gruplarda oranların birbirlerine yakın bulunduğu belirtilmelidir. Katılmayanlar ve yalnızca 1 öneriye imza atanlar açısından dağılıma bakıldığında ise $\mathrm{DSP}+\mathrm{YTP}+\mathrm{CHP}+\mathrm{ÖDP}$ grubu dışındaki diğer tüm grupların milletvekillerinin yarısından fazlasının (MHP+BBP'nin milletvekillerinde yaklaşık \%70) bu iki kategoride yer aldığı görülmektedir. Genele ilişkin düzenlemelerde Meclis'in sol kanadının daha aktif bir tutum sergilediği söylenebilir.

Uğraş alanına ait dağılım ve ulusal düzenleme ilişkisine bakıldığında çiftçi, tüccar-işadamı gruplarının genel düzenlemelere daha ilgisiz kaldıkları söylenebilir. Her iki grubun da yarıya yakını genel düzenlemelere ilişkin yasa önerilerine imza vermemişlerdir. Buna karşılık hakim ve savcılar içinde bu alanda önerge vermeyen milletvekili bulunmamaktadır. Ögretim üyeleri ve bürokratlar sayıca fazla olmalarına rağmen önemli ölçüde pasif bir milletvekili grubu barındırmaktadırlar. Buna karşılık genel düzenlemelerde çok aktif katılım sergileyen milletvekillerinin tamamı bürokrasi kökenlidir. Avukatlar genel düzenlemeler konusunda aktif sayılabilecek uğraş alanı grupları olarak değerlendirebilirler. Başka bir ifade ile ulusal düzenlemelerde hukukçu milletvekilleri aktif bir katılım göstermişlerdir.

\section{YEREL ÇIKARLAR ve YASAMA ETKINLIĞ́̇}

Bu başlık altında, milletvekillerinin seçildikleri il ve yakın bölgesini ilgilendiren veya doğum yeri ile ilgili fayda sağlayıcı öneriler değerlendirilmektedir (Bu grup altında toplanan yasa önerilerine; bir grup Konya milletvekili tarafından verilen Konya Ovası ve Orta Anadolu Bölge kalkınma İdaresi Kuruluş ve Görevleri Hakkındaki yasa önerisi; yine Kayseri ilinde Kayseri Teknik Üniversitesi adı altında yeni bir üniversite açılması yönündeki yasa önerisi örnek olarak verilebilir). Yine kendi bölgesine bir kazanım sağlamak amacıyla, milletvekilinin başka bir yerel talebi dile getiren öneriye imza atması durumu da bu çerçevede değerlendirilmektedir. Örneğin kendi iline üniversite açılması için öneri veren bir milletvekilinin, bu öneriye imza atan başka bir milletvekilinin kendi iline üniversite açılması için verdiği öneriyi desteklemesi gibi.

Tablo.11: Milletvekilinin Partisi/Yasama Etkinliği

\begin{tabular}{|c|c|c|c|c|c|c|c|c|c|c|c|c|c|c|}
\hline \multirow[b]{2}{*}{. } & \multicolumn{2}{|c|}{0} & \multicolumn{2}{|c|}{$1-3$} & \multicolumn{2}{|c|}{$4-6$} & \multicolumn{2}{|c|}{$7-10$} & \multicolumn{2}{|c|}{ 11-19 } & \multicolumn{2}{|c|}{$20-30$} & \multirow[t]{2}{*}{$T$} & \multirow[t]{2}{*}{$\mathrm{T} \%$} \\
\hline & $\mathbf{N}$ & $\%$ & $\mathbf{N}$ & $\%$ & $\mathbf{N}$ & $\%$ & $\mathbf{N}$ & $\%$ & $\mathbf{N}$ & $\%$ & $\mathbf{N}$ & $\%$ & & \\
\hline ANAP+YP & 22 & 29,3 & 38 & 50,7 & 14 & 18,7 & 1 & 1,3 & 0 & 0 & 0 & 0 & 75 & 100 \\
\hline $\begin{array}{l}\mathrm{DSP}+\mathrm{YTP}+ \\
\mathrm{CHP}+\mathrm{ODPP}\end{array}$ & 32 & 25,4 & 61 & 48,4 & 30 & 23,8 & 3 & 2,4 & 0 & 0 & 0 & 0 & 126 & 100 \\
\hline DYP & 31 & 37,8 & 40 & 48,9 & 7 & 8,5 & 3 & 3,6 & 0 & 0 & 1 & 1,2 & 82 & 100 \\
\hline $\mathrm{MHP}+\mathrm{BBP}$ & 49 & 37,4 & 63 & 48,1 & 17 & 13 & 0 & 0 & 2 & 1,5 & 0 & 0 & 131 & 100 \\
\hline $\mathrm{SP}+\mathrm{AKP}$ & 27 & 25,5 & 69 & 65,1 & 8 & 7,5 & 2 & 1,9 & 0 & 0 & 0 & 0 & 106 & 100 \\
\hline BAĞIMSIZ & 9 & 32,1 & 17 & 60,8 & 2 & 7,1 & 0 & 0 & 0 & 0 & 0 & 0 & 28 & 100 \\
\hline G.Dogu Anadolu & 18 & 33,3 & 34 & 63 & 2 & 3,7 & 0 & 0 & 0 & 0 & 0 & 0 & 54 & 100 \\
\hline
\end{tabular}

Tablo.12: Milletvekilinin Uğraş Alanı/Ulusal Yasama Etkinliği

\begin{tabular}{|c|c|c|c|c|c|c|c|c|c|c|c|c|c|c|}
\hline & \multicolumn{2}{|c|}{0} & \multicolumn{2}{|c|}{$1-3$} & \multicolumn{2}{|c|}{$4-6$} & \multicolumn{2}{|c|}{7.9} & \multicolumn{2}{|c|}{ 11-19 } & \multicolumn{2}{|c|}{30} & \multirow[t]{2}{*}{$\mathbf{T}$} & \multirow[t]{2}{*}{$\mathrm{T} \%$} \\
\hline & $\mathbf{N}$ & $\%$ & $\mathbf{N}$ & $\%$ & $\mathbf{N}$ & $\%$ & $\mathbf{N}$ & $\%$ & $\mathbf{N}$ & $\%$ & $\mathbf{N}$ & $\%$ & & \\
\hline Ögretim Üyesi & 20 & 31,2 & 34 & 53,2 & 10 & 15,6 & 0 & 0 & 0 & 0 & 0 & 0 & 64 & 100 \\
\hline Bürokrat & 26 & 35,2 & 36 & 48,6 & 7 & 9,5 & 1 & 1,3 & 3 & 4,1 & 1 & 1,3 & 74 & 100 \\
\hline Sağlık Gru. Serb. & 10 & 21,7 & 31 & 67,4 & 5 & 10,9 & 0 & 0 & 0 & 0 & 0 & 0 & 46 & 100 \\
\hline Avukat & 12 & 21,4 & 26 & 46,4 & 13 & 23,3 & 5 & 8,9 & 0 & 0 & 0 & 0 & 56 & 100 \\
\hline Mühendis & 29 & 35,4 & 37 & 45,1 & 15 & 18,3 & 1 & 1,2 & 0 & 0 & 0 & 0 & 82 & 100 \\
\hline İş Adamı & 28 & 45,2 & 31 & 50 & 3 & 4,8 & 0 & 0 & 0 & 0 & 0 & 0 & 62 & 100 \\
\hline Hakim-Savc1 & 0 & 0 & 2 & 50 & 2 & 50 & 0 & 0 & 0 & 0 & 0 & 0 & 4 & 100 \\
\hline Mali Müşavir & 2 & 13,3 & 11 & 73,3 & 1 & 6,7 & 1 & 6,7 & 0 & 0 & 0 & 0 & 15 & 100 \\
\hline Sanayici & 8 & 36,4 & 13 & 59 & 1 & 4,6 & 0 & 0 & 0 & 0 & 0 & 0 & 22 & 100 \\
\hline Çiftçi & 11 & 49,5 & 11 & 49,5 & 0 & 0 & 0 & 0 & 0 & 0 & 0 & 0 & 22 & 100 \\
\hline İş̧i-Sendikacı & 1 & 20 & 3 & 60 & 1 & 20 & 0 & 0 & 0 & 0 & 0 & 0 & 5 & 100 \\
\hline Özel Sektör Yön. & 13 & 27,1 & 22 & 45,8 & 13 & 27,1 & 0 & 0 & 0 & 0 & 0 & 0 & 48 & 100 \\
\hline Memur-Ögretmen & 10 & 20,8 & 31 & 64,6 & 7 & 14,6 & 0 & 0 & 0 & 0 & 0 & 0 & 48 & 100 \\
\hline
\end{tabular}


21. Dönemde 34 ilin milletvekillerinin tamamının yerel çıkarlara ilişkin yasa önerilerine imza verdikleri görülmektedir. $\mathrm{Bu}$ iller içinde Kocaeli, Manisa, Kahramanmaraş ve Diyarbakır gibi nüfus olarak önde gelen iller bulunmaktadır. Bunun dışındakiler 6 ve aşağı sayıda milletvekili çıkaran illerdir. Ağırlı Meclis'e 3 veya 2 temsilci gönderen küçük illerdedir. Yine Antalya, Kayseri, Trabzon, Şanllurfa milletvekillerinin de yerel çıkarlara dönük önerilerde etkin oldukları görülmektedir. Buna karşılık büyük kentlerin milletvekilleri yerel konularda daha pasif bir tutum izlemişlerdir. Ankara'da 9 (\%32,1), İstanbul'da 26 (\%38,2), İzmir'de 8 (\%33,3), Adana'da 5 (\%35,7) milletvekili yerel önerilere imza vermemişlerdir. Pasif tutum yalnızca TBMM'ye çok milletvekili gönderen illere özgü bir olgu değildir. Örneğin Aydın, Malatya, Kırklareli, Sinop ve Çanakkale gibi Meclis'e az sayıda milletvekili gönderen illerde de yerel nitelikteki önerilere soğuk bir tutum görülmektedir.

Marmara Bölgesi milletvekilleri yerel çıkarlara ilişkin önerilerde daha pasif bir tutuma sahiptirler. Bu bölgeyi Ege Bölgesi izlemektedir. Marmara Bölgesi milletvekillerinin \%74'ü ya hiç önerge vermemiş ya da bir ile üç arasında öneriye imza atmışlardır (Tablo.13). Karadeniz ve İç Anadolu Bölgesi milletvekillerinin (Ankara dışında) yerel konulara oldukça duyarlı bir tutum sergiledikleri, Akdeniz, Doğu ve Güney Doğu Anadolu Bölgesi milletvekillerinin bu iki bölgeyi izledikleri görülmektedir.

Yerel çıkarlarla partiler arasındaki ilişkiye bakıldığında ise $\mathrm{SP}+\mathrm{AKP}$ ile $\mathrm{MHP}+\mathrm{BBP} \quad \mathrm{SP}+\mathrm{AKP}$ grubunda yerel çıarlarla ilişkili öneri vermeyen milletvekili oranı $\% 2,8$ gibi oldukça düşük bir düzeydedir. $\mathrm{Bu}$ oran $\mathrm{DSP}+\mathrm{YTP}+\mathrm{CHP}+\mathrm{O} D \mathrm{P}$ grubunda $\% 48,4$ 'e ulaşmaktadır. MHP+BBP grubunda ise yerel çıkarlarla ilgili öneriye imza atmayanlar \%7,6 ile ikinci en az oranı oluşturmaktadırlar. DSP+YTP+CHP+ÖDP grubu yerel çıkarlara karşı en soğuk tutuma sahip gruptur.
Bunu \%30,7 ile ANAP+YP; \%20.7 ile DYP izlemektedir. Meclis'in en sağdaki kanadının 21. dönem yasama etkinliğinde yerel çıkarlarla ilişkin daha aktif bir tutum içinde olduğu, buna karşılık sol kanadın bu alanda oldukça pasif bir etkinlik dönemi geçirdiği söylenebilir.

Yerel çıkarlarla ilgili yasama etkinliğine katılımda da $\mathrm{SP}+\mathrm{AKP}$ ve $\mathrm{MHP}+\mathrm{BBP}$ grubu oldukça aktiftir. ANAP+YP grubunu \%56'sı 1-3 kategorisinde önergeye imza atmışlardır. Aynı kategoride $\mathrm{MHP}+\mathrm{BBP}$ oranı \%32,8 iken bir sonraki (4-6) kategoride ANAP \%12'ye gerilerken, MHP grubu \%45.1'e yükselmektedir. $\mathrm{SP}+\mathrm{AKP}$ grubu ise en aktif gruptur. Bu grup 7-9 kategorisinde \%34,9 oranında bir katılım göstermektedir.

Uğraş alanları açısından yerel çıkarlara ait yasa önerilerine bakıldığında özel sektör yöneticilerinin bu konuda en pasif grubu, memur-öğretmen grubunun ise en aktif grubu oluşturduğu, bu grubu işadamı, tüccar ve sağlıkla ilgili serbest meslek grubundan gelen milletvekillerinin izlediği görülmektedir (Tablo.15). Buna karşılık muhasebeci- mali müşavir, mühendis ve teknik elemanlar, sanayiciler, çiftçiler ve avukatlar daha pasif bir tutum içerisindedir. Çiftçilerin yerel konularla ilgili daha pasif bir tutum sergilemeleri dikkat çekicidir.

Bir diğer dikkat çekici bulgu öğretim üyelerinin yerel çıkarlar konusunda gösterdikleri aktif tutumdur. Özellikle illere üniversite açılması, ilçelere meslek yüksek okulu kurulması, yeni fakülte açılmasına dönük önerilerde bu gruptan milletvekillerinin aktif bir katılım gösterdikleri ve farklı önerileri destekledikleri gözlenmektedir. Bürokrat, memur-öğretmen grubunun, öğretim üyeleri ile birlikte ele alındığında diğer uğraş alanı gruplarına göre aktif oldukları, başka bir ifade ile kamu görevlilerinin yerel çıkarlarla ilgili önerilerde, özel uğraş alanı gruplarına göre daha aktif davrandıkları belirtilebilir.

Tablo.13: Milletvekilinin Bölgesi/Ulusal Yasama Etkinliği

\begin{tabular}{|c|c|c|c|c|c|c|c|c|c|c|c|c|c|c|}
\hline & \multicolumn{2}{|c|}{0} & \multicolumn{2}{|c|}{$1-3$} & \multicolumn{2}{|c|}{$4-6$} & \multicolumn{2}{|c|}{$7-9$} & \multicolumn{2}{|c|}{$10-12$} & \multicolumn{2}{|c|}{$13-19$} & \multirow[t]{2}{*}{$\mathbf{T}$} & \multirow[t]{2}{*}{$\mathrm{T} \%$} \\
\hline & $\mathbf{N}$ & $\%$ & $\mathbf{N}$ & $\%$ & $\mathbf{N}$ & $\%$ & $\mathbf{N}$ & $\%$ & $\mathbf{N}$ & $\%$ & $\mathbf{N}$ & $\%$ & & \\
\hline Marmara & 44 & 34,1 & 52 & 40,3 & 19 & 14,7 & 9 & 7 & 4 & 3,1 & 1 & 0,8 & 129 & 100 \\
\hline Ege & 17 & 23,9 & 38 & 53,5 & 14 & 19,8 & 1 & 1,4 & 1 & 1,4 & 0 & 0 & 71 & 100 \\
\hline Akdeniz & 12 & 17,6 & 25 & 36,9 & 18 & 26,5 & 9 & 13,2 & 4 & 5,8 & 0 & 0 & 68 & 100 \\
\hline İç Anadolu & 19 & 20,4 & 32 & 34,4 & 23 & 24,7 & 15 & 16,1 & 2 & 2,2 & 2 & 2,2 & 93 & 100 \\
\hline Karadeniz & 10 & 13,1 & 33 & 43,4 & 20 & 26,4 & 7 & 9,3 & 4 & 5,2 & 2 & 2,6 & 76 & 100 \\
\hline Doğu Anadolu & 11 & 19,3 & 20 & 35,2 & 14 & 24,6 & 9 & 15,7 & 2 & 3,5 & 1 & 1,7 & 57 & 100 \\
\hline Güney D. And & 8 & 14,8 & 27 & 50 & 12 & 22,2 & 5 & 9,3 & 2 & 3,7 & 0 & 0 & 54 & 100 \\
\hline
\end{tabular}

Tablo.14: Milletvekilinin Partisi/Ulusal Yasama Etkinliği

\begin{tabular}{|c|c|c|c|c|c|c|c|c|c|c|c|c|c|c|}
\hline & \multicolumn{2}{|c|}{ 0 } & \multicolumn{2}{|c|}{$1-3$} & \multicolumn{2}{|c|}{$4-6$} & \multicolumn{2}{|c|}{7.9} & \multicolumn{2}{|c|}{$10-12$} & \multicolumn{2}{|c|}{$13-19$} & \multirow[t]{2}{*}{$\mathbf{T}$} & \multirow[t]{2}{*}{$\mathrm{T} \%$} \\
\hline . & $\mathbf{N}$ & $\%$ & $\mathbf{N}$ & $\%$ & $\mathbf{N}$ & $\%$ & $N$ & $\%$ & $\mathbf{N}$ & $\%$ & $\mathbf{N}$ & $\%$ & & \\
\hline ANAP+YP & 23 & 30,7 & 42 & 56 & 9 & 12 & 1 & 1,3 & 0 & 0 & 0 & 0 & 75 & 100 \\
\hline $\begin{array}{l}\mathrm{DSP}+\mathrm{YTP}+ \\
\mathrm{CHP}+\mathrm{ODDP}\end{array}$ & 61 & 48,4 & 60 & 47,6 & 4 & 3,2 & 1 & 0,8 & 0 & 0 & 0 & 0 & 126 & 100 \\
\hline DYP & 17 & 20,7 & 47 & 57,4 & 15 & 18,3 & 1 & 1,2 & 2 & 2,4 & 0 & 0 & 82 & 100 \\
\hline $\mathrm{MHP}+\mathrm{BBP}$ & 10 & 7,6 & 43 & 32,8 & 59 & 45,1 & 13 & 9,9 & 4 & 3,1 & 2 & 1,5 & 131 & 100 \\
\hline SP+AKP & 3 & 2,8 & 22 & 20,8 & 29 & 27,4 & 37 & 34,9 & 11 & 10,3 & 4 & 3,8 & 106 & 100 \\
\hline BAĞIMSIZ & 7 & 25 & 13 & 46,4 & 4 & 14,2 & 2 & 7,2 & 2 & 7,2 & 0 & 0 & 28 & 100 \\
\hline
\end{tabular}


VI. UĞRAŞ ALANINA AİT ÇIKARLAR VE
YASAMA ETKINLİĞ

Bu kategoride milletvekilinin yürüttüğü uğraş alanı ve üyesi bulunduğu meslek örgütleri ve derneklerle ilgili olarak verdiği veya desteklediği öneriler yer almaktadır (Bu grup altında toplanan yasa önerilerine; 547 sayılı Devlet Memurları Yasasına sağlık hizmetleri tazminatı konusunda değişiklik yapılmasını içeren 547 sayılı yasa önerisi; yine Gümrük Yasasında değişikliğe gidilerek, Gümrük Komisyoncusu Yardımcılarına iki yıl süre ile sınav şartı aranmaksızın Komisyoncu belgesi verilmesini içeren yasa önerisi örnek olarak verilebilir). 21. Dönem yasama etkinliği uğraş alanına ait çıkarlar açısından yoğun bir yasama etkinliğine sahne olmamıştır. Genel değerlendirmede uğraş alanına ait çıkarlarla ilgili öneriler 134 ile 4. sıradadır. Öncelikle bölgesel açıdan bu önerilerde katılmama eğilimi tüm bölgelerde \%69'un üstündedir. Oransal olarak Marmara ve Ege Bölgesinde daha duyarlı bir tutum gözlenmektedir. Güneydoğu ve Karadeniz Bölgeleri'nde ise oldukça pasif bir tutum sergilenmiştir.

Genel dağılıma bakıldığında, belirtildiği gibi Ege Bölgesi'nin ve Marmara Bölgesi milletvekillerinin bu konuda daha aktif oldukları belirtilebilir (Tablo 16).

Partisel dağılıma bakıldığında uğraş alanına ait çıarlar konusunda $\mathrm{MHP}+\mathrm{BBP}$ ve $\mathrm{DSP}+\mathrm{YTP}+\mathrm{CHP}+\mathrm{ÖDP}$ gruplarının biraz daha aktif oldukları belirtilebilir. En pasif grubun SP+AKP grubu olduğu, genelde pasif tutum gösterse de ANAP+YP grubunun bu konuda bazı aktif milletvekillerine sahip bulunduğu gözlenmektedir (Tablo.17).

Tablo.15: Milletvekilinin Uğraş Alanı/Yerel Yasama Etkinliği

\begin{tabular}{|c|c|c|c|c|c|c|c|c|c|c|c|c|c|c|}
\hline & \multicolumn{2}{|c|}{ 0 } & \multicolumn{2}{|c|}{$1-3$} & \multicolumn{2}{|c|}{$4-6$} & \multicolumn{2}{|c|}{$7-9$} & \multicolumn{2}{|c|}{$10-12$} & \multicolumn{2}{|c|}{$13-19$} & \multirow[t]{2}{*}{$\mathbf{T}$} & \multirow[t]{2}{*}{$\mathrm{T} \%$} \\
\hline & $\mathbf{N}$ & $\%$ & $\mathbf{N}$ & $\%$ & $\mathbf{N}$ & $\%$ & $\mathbf{N}$ & $\%$ & $\mathbf{N}$ & $\%$ & $\mathbf{N}$ & $\%$ & & \\
\hline Ögretim Úyesi & 14 & 21,8 & 23 & 35,9 & 18 & 28,2 & 5 & 7,8 & 4 & 6,3 & 0 & 0 & 64 & 100 \\
\hline Bürokrat & 14 & 16,7 & 35 & 53,6 & 11 & 13,1 & 10 & 11,9 & 3 & 3,5 & 1 & 1,2 & 74 & 100 \\
\hline $\begin{array}{l}\text { Saglik Gru. } \\
\text { Serbest Mes. }\end{array}$ & 8 & 17,4 & 18 & 39,1 & 11 & 23,9 & 4 & 8,7 & 4 & 8,7 & 1 & 2,2 & 46 & 100 \\
\hline Avukat & 13 & 23,2 & 23 & 41,1 & 14 & 25 & 6 & 10,7 & 0 & 0 & 0 & 0 & 56 & 100 \\
\hline Mühendis & 22 & 26,8 & 35 & 42,8 & 16 & 19,5 & 6 & 7,3 & 1 & 1,2 & 2 & 2,4 & 82 & 100 \\
\hline İş Adamı & 10 & 16,1 & 26 & 42 & 19 & 30,6 & 5 & 8,1 & 1 & 1,6 & 1 & 1,6 & 62 & 100 \\
\hline Hakim-Savc1 & 0 & 0 & 3 & 75 & 1 & 25 & 0 & 0 & 0 & 0 & 0 & 0 & 4 & 100 \\
\hline Mali Müşavir & 4 & 26,6 & 6 & 40 & 1 & 6,7 & 3 & 20 & 1 & 6,7 & 0 & 0 & 15 & 100 \\
\hline Sanayici & 6 & 27,3 & 8 & 36,4 & 3 & 13,6 & 3 & 13,6 & 2 & 9,1 & 0 & 0 & 22 & 100 \\
\hline Çiftçi & 6 & 27,4 & 11 & 50 & 4 & 18,1 & 1 & 4,5 & 0 & 0 & 0 & 0 & 22 & 100 \\
\hline İşci-Sendikacı & 1 & 20 & 3 & 60 & 0 & 0 & 1 & 20 & 0 & 0 & 0 & 0 & 5 & 100 \\
\hline Özel Sektör Yön. & 16 & 33,3 & 23 & 48 & 7 & 14,5 & 2 & 4,1 & 0 & 0 & 0 & 0 & 48 & 100 \\
\hline Memur-Öğretm. & 7 & 14,6 & 13 & 27,1 & 15 & 31,2 & 9 & 18,7 & 3 & 6,2 & 1 & 2,2 & 48 & 100 \\
\hline
\end{tabular}

Tablo.16: Milletvekilinin Bölgesi/Uğraş Alanına Ait Yasama Etkinliği

\begin{tabular}{|c|c|c|c|c|c|c|c|c|c|c|c|c|c|c|c|c|c|c|c|c|}
\hline & \multicolumn{2}{|c|}{ 0 } & \multicolumn{2}{|c|}{1} & \multicolumn{2}{|c|}{2} & \multicolumn{2}{|c|}{3} & \multicolumn{2}{|c|}{4} & \multicolumn{2}{|c|}{5} & \multicolumn{2}{|c|}{7} & \multicolumn{2}{|c|}{8} & \multicolumn{2}{|c|}{10} & \multirow[t]{2}{*}{$\mathbf{T}$} & \multirow[t]{2}{*}{$\mathrm{T} \%$} \\
\hline & $\mathbf{N}$ & $\%$ & $\mathbf{N}$ & $\%$ & $\mathbf{N}$ & $\%$ & $\mathbf{N}$ & $\%$ & $\mathbf{N}$ & $\%$ & $\mathbf{N}$ & $\%$ & $\mathbf{N}$ & $\%$ & $\mathbf{N}$ & $\%$ & $\mathbf{N}$ & $\%$ & & \\
\hline Marmara & 89 & 69 & 27 & 20,9 & 8 & 6,2 & 2 & 1,5 & 1 & 0,8 & 0 & 0 & 1 & 0,8 & 1 & 0,8 & 0 & 0 & 129 & 100 \\
\hline Ege & 50 & 70,4 & 15 & 21,2 & 2 & 2,8 & 1 & 1,4 & 0 & 0 & 2 & 2,8 & 1 & 1,4 & 0 & 0 & 0 & 0 & 71 & 100 \\
\hline Akdeniz & 51 & 75 & 10 & 14,8 & 5 & 7,3 & 2 & 2,9 & 0 & 0 & 0 & 0 & 0 & 0 & 0 & 0 & 0 & 0 & 68 & 100 \\
\hline İç Anadolu & 69 & 74,2 & 17 & 18,3 & 3 & 3,2 & 2 & 2,1 & 0 & 0 & 1 & 1,1 & 0 & 0 & 0 & 0 & 1 & 1,1 & 93 & 100 \\
\hline Karadeniz & 65 & 85,6 & 9 & 11,8 & 2 & 2,6 & 0 & 0 & 0 & 0 & 0 & 0 & 0 & 0 & 0 & 0 & 0 & 0 & 76 & 100 \\
\hline Doğu Anadolu & 45 & 78,9 & 6 & 10,5 & 5 & 8,8 & 0 & 0 & 0 & 0 & 1 & 1,8 & 0 & 0 & 0 & 0 & 0 & 0 & 57 & 100 \\
\hline Güney D. And & 46 & 85,2 & 8 & 14,8 & 0 & 0 & 0 & 0 & 0 & 0 & 0 & 0 & 0 & 0 & 0 & 0 & 0 & 0 & 54 & 100 \\
\hline
\end{tabular}

Tablo.17: Milletvekilinin Partisi/Uğraş Alanuna Ait Yasama Etkinliği

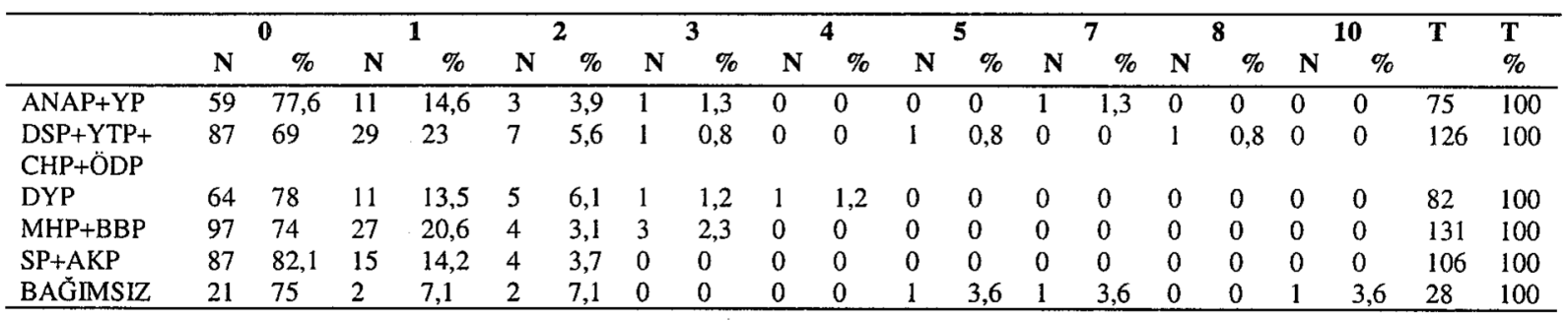


Uğraş alanı grupları ile uğraş alanına ait çıkarlar arasındaki ilişkiye bakıldığında muhasebeci-mali müşavirler uğraş alanı grubunun en aktif grubu temsil ettikleri belirtilebilir. Bunu ögretim üyeleri ve çiftçiler izlemektedir (Tablo 18).

Bürokratlar genelde aktif bir katılım göstermeseler de, uğraş alanına ait çıkarlarla ilgili aktif milletvekilleri barındırmaktadırlar. Memur-ögretmen grubu ve sanayiciler uğraş alanına ait çıkarlarla ilgili en pasif uğraş alanı grubunu oluşturmaktadırlar. Yerel çıkarlara karşı ilgisiz çiftçilerin uğraş alanına ait çıkarlar konusunda daha aktif olmaları, tersine yerel çıkarlar konusunda aktif bir tutuma sahip bulunan memur-ögretmen grubunun uğraş alanına ait çıkarlar konusunda daha pasif bir tavır sergilemeleri dikkat çekicidir.

Öğretim üyeleri dışında kamu çalışanlarının uğraş alanına ait çıkarlar konusunda daha ilgisiz kaldıkları, buna karşıllık diğer uğraş alanı gruplarının da uğraş alanına ait çıkarlar konusunda aktif bir etkinlik sergilemedikleri belirtilebilir. Sanayicilerde, sendikacı-işçi milletvekilleri içinde teknik elemanlarda özel sektör yöneticilerinde uğraş alanına ait çıkarlar paralelinde yasama etkinliği derecesi oldukça düşüktür.

\section{SIYYASET, PARTI POLÍTÍKALARI VE MILLETVEKILII DAVRANIȘI}

Son olarak milletvekillerinin kendi partilerinin kamuoyunda temsil ettiği çıkarları temsil eden parti lideri, yöneticisi, grup başkanı milletvekillerinin öncülük ettiği yasa önerileri ile yine genel parti politikasını yansıtmakta belirleyici olan ve 21 . Dönem yasama etkinliklerinde önemli bir yeri olan anayasa değişiklikleri ile ilgili yasa önerileri aynı grupta toplanarak değerlendirilmektedir. Ayrıca doğrudan siyasal hayatın işleyişini ilgilendiren öneriler de bu değerlendirmeye eklenmiştir. Bu grup altında milletvekillerinin kendi partisi ve siyaset uğraş alanı ile yakından ilgili önergelerdeki tutumu analiz edilmeye çaba harcanmaktadır. Yine analiz bölgesel, partisel ve uğraş alanı düzeyinde yapılmaktadır.

Bölgesel açıdan parti politikaları ve milletvekillerinin eğilimi incelendiğinde genel olarak bütün bölgelerde parti politikalarını yansıtan önerilere katılımın yüksek olduğu görülmektedir (Tablo.19). Bütün bölgelerde katılmama oranı yaklaşık olarak \%20 ve altındadır. Buna karşılık, Güneydoğu Anadolu Bölgesi, Marmara Bölgesi, İç Anadolu ve Ege Bölgesi katılmama eğilimi açısından önde gelmektedir. Ülkenin en geri kalmış bölgesinin üç gelişmiş bölgenin önünde gelmesi dikkat çekicidir. Parti politikalarına uyumluluğun, bireysel milletvekili davranışının öne çıktığı daha çok gelişmiş bölge temsilcilerinin özelliği olduğu varsayıldığında bu durum önem kazanmaktadır.

Güney Doğu Anadolu Bölgesi'nden gelen milletvekillerinin partinin genel politikası konusunda oransal olarak en isteksiz grubu oluşturdukları görülmektedir. En uyumlu bölgeler ise Doğu Anadolu, Karadeniz ve Akdeniz Bölgeleridir.

Tablo.18: Milletvekilinin Uğraş Alanı/Uğraş Alanına Ait Yasama Etkinliği

\begin{tabular}{|c|c|c|c|c|c|c|c|c|c|c|c|c|c|c|c|c|c|c|c|c|}
\hline & \multicolumn{2}{|c|}{0} & \multicolumn{2}{|c|}{1} & \multicolumn{2}{|c|}{2} & \multicolumn{2}{|c|}{3} & \multicolumn{2}{|c|}{4} & \multicolumn{2}{|c|}{5} & \multicolumn{2}{|c|}{7} & \multicolumn{2}{|c|}{8} & \multicolumn{2}{|c|}{10} & \multirow[t]{2}{*}{$\mathbf{T}$} & \multirow[t]{2}{*}{$\mathbf{T} \%$} \\
\hline & $\mathbf{N}$ & $\%$ & $\mathbf{N}$ & $\%$ & $\mathbf{N}$ & $\%$ & $\mathbf{N}$ & $\%$ & $\mathbf{N}$ & $\%$ & $\mathbf{N}$ & $\%$ & $\mathbf{N}$ & $\%$ & $\mathbf{N}$ & $\%$ & $\mathbf{N}$ & $\%$ & & \\
\hline Ốgretim Üyesi & 38 & 59,4 & 19 & 29,7 & 4 & 6,2 & 3 & 4,7 & 0 & 0 & 0 & 0 & 0 & 0 & 0 & 0 & 0 & 0 & 64 & 100 \\
\hline Bürokrat & 61 & 82,5 & 5 & 6,9 & 3 & 4,1 & 1 & 1,3 & 0 & 0 & 2 & 2,6 & 1 & 1,3 & 0 & 0 & 1 & 1,3 & 74 & 100 \\
\hline $\begin{array}{l}\text { Saglık Gru. } \\
\text { Serbest Mes. }\end{array}$ & 30 & 65,3 & 10 & 21,7 & 4 & 8,8 & 0 & 0 & 0 & 0 & 1 & 2,1 & 0 & 0 & 1 & 2,1 & 0 & 0 & 46 & 100 \\
\hline Avukat & 38 & 67,8 & 12 & 21,5 & 3 & 5,3 & 1 & 1,8 & 0 & 0 & 1 & 1,8 & 1 & 1,8 & 0 & 0 & 0 & 0 & 56 & 100 \\
\hline Mühendis & 64 & 76,8 & 11 & 13,2 & 6 & 7,2 & 1 & 1,2 & 0 & 0 & 0 & 0 & 0 & 0 & 0 & 0 & 0 & 0 & 82 & 100 \\
\hline İş Adamı & 54 & 86,4 & 7 & 11,2 & 1 & 1,6 & 0 & 0 & 0 & 0 & 0 & 0 & 0 & 0 & 0 & 0 & 0 & 0 & 62 & 100 \\
\hline Hakim-Savcı & 3 & 75 & 1 & 25 & 0 & 0 & 0 & 0 & 0 & 0 & 0 & 0 & 0 & 0 & 0 & 0 & 0 & 0 & 4 & 100 \\
\hline Mali Müşavir & 6 & 39,6 & 8 & 52,8 & 1 & 6,6 & 0 & 0 & 0 & 0 & 0 & 0 & 0 & 0 & 0 & 0 & 0 & 0 & 15 & 100 \\
\hline Sanayici & 19 & 85,5 & 3 & 13,5 & 0 & 0 & 0 & 0 & 0 & 0 & 0 & 0 & 0 & 0 & 0 & 0 & 0 & 0 & 22 & 100 \\
\hline Çiftçi & 15 & 17,5 & 4 & 18 & 2 & 9 & 0 & 0 & 1 & 4,5 & 0 & 0 & 0 & 0 & 0 & 0 & 0 & 0 & 22 & 100 \\
\hline İş̧i-Sendikacı & 4 & 80 & 1 & 20 & 0 & 0 & 0 & 0 & 0 & 0 & 0 & 0 & 0 & 0 & 0 & 0 & 0 & 0 & 5 & 100 \\
\hline Ozel Sek. Yön. & 41 & 86,1 & 5 & 10,5 & 1 & 2,1 & 1 & 2,1 & 0 & 0 & 0 & 0 & 0 & 0 & 0 & 0 & 0 & 0 & 48 & 100 \\
\hline Memur-Ögrt. & 42 & 88,2 & 6 & 12,6 & 0 & 0 & 0 & 0 & 0 & 0 & 0 & 0 & 0 & 0 & 0 & 0 & 0 & 0 & 48 & 100 \\
\hline
\end{tabular}

Tablo.19: Milletvekilinin Bölgesi/Parti Politikası Yasama Etkinliği

\begin{tabular}{|c|c|c|c|c|c|c|c|c|c|c|c|c|c|c|c|c|c|c|}
\hline & \multicolumn{2}{|c|}{ 0 } & \multicolumn{2}{|c|}{$1-3$} & \multicolumn{2}{|c|}{$4-6$} & \multicolumn{2}{|c|}{7.9} & \multicolumn{2}{|c|}{$10-12$} & \multicolumn{2}{|c|}{ 13-15 } & \multicolumn{2}{|c|}{$16-18$} & \multicolumn{2}{|c|}{$19+$} & \multirow[t]{2}{*}{$\mathbf{T}$} & \multirow[t]{2}{*}{$\mathbf{T} \%$} \\
\hline & $\mathbf{N}$ & $\%$ & $\mathbf{N}$ & $\%$ & $\mathbf{N}$ & $\%$ & $\mathbf{N}$ & $\%$ & $\mathbf{N}$ & $\%$ & $\mathbf{N}$ & $\%$ & $\mathbf{N}$ & $\%$ & $\mathbf{N}$ & $\%$ & & \\
\hline Marmara & 24 & 18,6 & 52 & 40,3 & 28 & 21,7 & 15 & 11,6 & 9 & 7 & 0 & 0 & 0 & 0 & 1 & $\overline{0,8}$ & 129 & 100 \\
\hline Ege & 13 & 18,3 & 27 & 38,1 & 18 & 25,4 & 7 & 9,8 & 3 & 4,2 & 2 & 2,8 & 1 & 1,4 & 0 & 0 & 71 & 100 \\
\hline Akdeniz & 7 & 10,3 & 20 & 29,4 & 16 & 23,5 & 10 & 14,7 & 8 & 11,8 & 5 & 7,3 & 0 & 0 & 2 & 3 & 68 & 100 \\
\hline İç Anadolu & 18 & 19,3 & 28 & 30,1 & 19 & 20,4 & 19 & 20,4 & 6 & 6,5 & 2 & 2,2 & 0 & 0 & 1 & 1,1 & 93 & 100 \\
\hline Karadeniz & 9 & 11,8 & 27 & 35,5 & 22 & 29 & 12 & 15,8 & 4 & 5,3 & 0 & 0 & 1 & 1,3 & 1 & 1,3 & 76 & 100 \\
\hline Doğu Anadolu & 7 & 12,3 & 14 & 24,6 & 17 & 29,8 & 9 & 15,8 & 4 & 7 & 4 & 7 & 2 & 3,5 & 0 & 0 & 57 & 100 \\
\hline Güney D. And & 11 & 20,4 & 18 & 33,3 & 15 & 27,8 & 6 & 11,1 & 2 & 3,7 & 2 & 3,7 & 0 & 0 & 0 & 0 & 54 & 100 \\
\hline
\end{tabular}


Partiler açısından dağılıma bakıldığında; parti politikasına en uyumlu grubun SP+AKP grubu olduğu görülmektedir (Tablo.20). Bu grup her kategoride katılım gösterdiği gibi, \%3,8 gibi çok düşük bir düzeyde katılmama davranışı sergilemiştir. En uyumsuz grubu ise ANAP+YP milletvekilleri oluşturmaktadırlar. Bu grupta $\% 40$ oranında bir katılmama oranı bulunmaktadır. $\mathrm{SP}+\mathrm{AKP}$ ve MHP+BBP grubu milletvekillerinin parti politikaları doğrultusunda daha aktif bir katılım sergiledikleri, diğer partilerde ise katılımın 1-6 kategorisi içinde yoğunlaştığı görülmektedir.

Uğraş alanı açısından parti politikalarına yönelik eğilimlerin dağılımına bakıldığında, en uyumlu grubun sağlık ve memur-öğretmen uğraş alanı grupları olduğu görülmektedir. Özellikle çiftçi ve bürokratların parti politikaları konusunda pasif bir kesimi barındırdıkları söylenebilir. Hukukçuların (avukatlar-hakim/savcı) parti politikaları konusunda diğer bir aktif grubu oluşturduğu, bürokratların, memur-öğretmenlerle birlikte bu konuda aktif tutum içinde bulunan milletvekillerini barındırdıkları belirtilebilir. 13 'ten fazla öneriye imza atan milletvekili içinde 6 bürokrat, 5 hukukçu, 4 memur-öğretmen ve 3 öğretim üyesi, diğer uğraş alanı gruplarında ise toplam 6 milletvekili bulunmaktadır (Tablo.21).

Belirtildiği gibi parti politikalarına uyum açısından anayasa değişikliği önergeleri önemli bir göstergedir [6] Anayasal zorunluluk olarak bu önergeler için milletvekili üye tam sayısının $1 / 3$ 'ünün imzası gerekmektedir. $\mathrm{Bu}$ nedenle anayasa değişikliği ile ilgili önergelerde Meclis grubu içinde veya bir diğer partiden katılım sağlanarak önerge verilmesi, dolayısıyla parti içi yönlendirmenin daha görünür hale gelmesi söz konusudur. Ayrıca bu önerilerde partiler arası dağılım, iktidar ve muhalefet partileri arasındaki farklılıklar da parti politikaları ile milletvekili davranışının açıklanmasında aydınlatıcı olabilmektedir. Tablo.22'de görüldüğü gibi hemen her siyasal parti bu konularda aktif tutum içindedir. Anayasa değișikleri konusunda imza vermeyen toplam üç milletvekili bulunmaktadır.

Tablo.20: Milletvekilinin Partisi/Parti Politikası Yasama Etkinliği

\begin{tabular}{|c|c|c|c|c|c|c|c|c|c|c|c|c|c|c|c|c|c|c|}
\hline & \multicolumn{2}{|c|}{ 0 } & \multicolumn{2}{|c|}{1.3} & \multicolumn{2}{|c|}{$4-6$} & \multicolumn{2}{|c|}{$7-9$} & \multicolumn{2}{|c|}{$10-12$} & \multicolumn{2}{|c|}{$13-15$} & \multicolumn{2}{|c|}{$16-18$} & \multicolumn{2}{|c|}{$19+$} & \multirow[t]{2}{*}{$\mathbf{T}$} & \multirow[t]{2}{*}{ T \% } \\
\hline & $\mathbf{N}$ & $\%$ & $\mathbf{N}$ & $\%$ & $\mathbf{N}$ & $\%$ & $\mathbf{N}$ & $\%$ & $\mathbf{N}$ & $\%$ & $\mathbf{N}$ & $\%$ & $\mathbf{N}$ & $\%$ & $\mathbf{N}$ & $\%$ & & \\
\hline $\mathrm{ANAP}+\mathrm{YP}$ & 30 & 40 & 35 & 46,7 & 8 & 10,7 & 1 & 1,3 & 1 & 1,3 & 0 & 0 & 0 & 0 & 0 & 0 & 75 & 100 \\
\hline $\begin{array}{l}\text { DSP+YTP+ } \\
\text { CHP+ÖDP }\end{array}$ & 20 & 15,8 & 68 & 54 & 32 & 25,4 & 6 & 4,8 & 0 & 0 & 0 & 0 & 0 & 0 & 0 & 0 & 126 & 100 \\
\hline DYP & 9 & 11 & 28 & 34,1 & 32 & 39 & 8 & 9,8 & 1 & 1,2 & 0 & 0 & 1 & 1,2 & 3 & 3,7 & 82 & 100 \\
\hline $\mathrm{MHP}+\mathrm{BBP}$ & 17 & 12,9 & 24 & 18,3 & 32 & 24,4 & 37 & 28,2 & 15 & 11,5 & 4 & 3,1 & 1 & 0,8 & 1 & 0,8 & 131 & 100 \\
\hline $\mathrm{SP}+\mathrm{AKP}$ & 4 & 3,8 & 24 & 22,6 & 24 & 22,6 & 25 & 23,6 & 16 & 15,2 & 10 & 9,4 & 2 & 1,9 & 1 & 0,9 & 106 & 100 \\
\hline BAGIMSIZ & 0 & 0 & 0 & 0 & 0 & 0 & 0 & 0 & 0 & 0 & 0 & 0 & 0 & 0 & 0 & 0 & 0 & 100 \\
\hline
\end{tabular}

Tablo.21: Milletvekilinin Uğraş Alanı/Parti Politikası Yasama Etkinliği

\begin{tabular}{|c|c|c|c|c|c|c|c|c|c|c|c|c|c|c|c|c|c|c|}
\hline & \multicolumn{2}{|c|}{0} & \multicolumn{2}{|c|}{$1-3$} & \multicolumn{2}{|c|}{$4-6$} & \multicolumn{2}{|c|}{7.9} & \multicolumn{2}{|c|}{$10-12$} & \multicolumn{2}{|c|}{$13-15$} & \multicolumn{2}{|c|}{$16-18$} & \multicolumn{2}{|c|}{$19+$} & \multirow[t]{2}{*}{$T$} & \multirow[t]{2}{*}{$\mathbf{T} \%$} \\
\hline & $\mathbf{N}$ & $\%$ & $\mathbf{N}$ & $\%$ & $\mathbf{N}$ & $\%$ & $\mathbf{N}$ & $\%$ & $\mathbf{N}$ & $\%$ & $\mathbf{N}$ & $\%$ & $\mathbf{N}$ & $\%$ & $\mathbf{N}$ & $\%$ & & \\
\hline Ögretim Üyesi & 12 & 18,8 & 17 & 26,6 & 20 & 31,2 & 7 & 10,9 & 5 & 7,8 & 3 & 4,7 & 0 & 0 & 0 & 0 & 64 & 100 \\
\hline Bürokrat & 20 & 27 & 25 & 33,8 & 15 & 20,3 & 5 & 6,8 & 3 & 4,1 & 4 & 5,4 & 1 & 1,3 & 1 & 1,3 & 74 & 100 \\
\hline $\begin{array}{l}\text { Saglık Gru. } \\
\text { Serbest Mes. }\end{array}$ & 4 & 8,7 & 19 & 41,3 & 11 & 23,9 & 6 & 13,1 & 4 & 8,7 & 2 & 4,3 & 0 & 0 & 0 & 0 & 46 & 100 \\
\hline Avukat & 9 & 16,1 & 17 & 30,4 & 11 & 19,6 & 11 & 19,6 & 4 & 7,1 & 2 & 3,6 & 1 & 1,8 & 1 & 1,8 & 56 & 100 \\
\hline Mühendis & 10 & 12,2 & 29 & 35,4 & 26 & 31,7 & 11 & 13,4 & 4 & 4,9 & 1 & 1,2 & 0 & 0 & 1 & 1,2 & 82 & 100 \\
\hline İs Adamı & 9 & 14,5 & 19 & 30,6 & 15 & 24,2 & 11 & 17,7 & 7 & 11,3 & 1 & 1,7 & 0 & 0 & 0 & 0 & 62 & 100 \\
\hline Hakim-Savct & 1 & 25 & 2 & 50 & 0 & 0 & 0 & 0 & 0 & 0 & 0 & 0 & 0 & 0 & 1 & 25 & 4 & 100 \\
\hline Mali Müşavir & 2 & 13,3 & 3 & 20 & 5 & 33,3 & 4 & 26,7 & 1 & 6,7 & 0 & 0 & 0 & 0 & 0 & 0 & 15 & 100 \\
\hline Sanayici & 3 & 13,6 & 9 & 40,9 & 6 & 27,3 & 2 & 9,1 & 2 & 9,1 & 0 & 0 & 0 & 0 & 0 & 0 & 22 & 100 \\
\hline Çiftçi & 7 & 31,8 & 7 & 31,8 & 6 & 27,3 & 2 & 9,1 & 0 & 0 & 0 & 0 & 0 & 0 & 0 & 0 & 22 & 100 \\
\hline İş̧̧i-Sendikacı & 0 & 0 & 3 & 60 & 0 & 0 & 1 & 20 & 1 & 20 & 0 & 0 & 0 & 0 & 0 & 0 & 5 & 100 \\
\hline Özel Sek. Yön & 10 & 20,8 & 25 & 52,1 & 6 & 12,5 & 5 & 10,4 & 1 & 2,1 & 1 & 2,1 & 0 & 0 & 0 & 0 & 48 & 100 \\
\hline Memur-Ögret. & 2 & 4,2 & 11 & 22,9 & 13 & 27,1 & 13 & 27 & 5 & 10,4 & 1 & 2,1 & 2 & 4,2 & 1 & 2,1 & 48 & 100 \\
\hline
\end{tabular}

Tablo.22: Milletvekilinin Uğraş Alanı/Parti Politikası Yasama Etkinliği

\begin{tabular}{|c|c|c|c|c|c|c|c|c|c|c|c|c|c|c|c|c|c|c|c|c|c|c|}
\hline & \multicolumn{2}{|c|}{0} & \multicolumn{2}{|c|}{1} & \multicolumn{2}{|c|}{2} & \multicolumn{2}{|c|}{3} & \multicolumn{2}{|c|}{4} & \multicolumn{2}{|c|}{5} & \multicolumn{2}{|c|}{6} & \multicolumn{2}{|c|}{7} & \multicolumn{2}{|c|}{8} & \multicolumn{2}{|c|}{9} & \multirow[t]{2}{*}{$\mathbf{T}$} & \multirow{2}{*}{$\begin{array}{l}\mathbf{T} \\
\%\end{array}$} \\
\hline & $\mathbf{N}$ & $\%$ & $\mathbf{N}$ & $\%$ & $\mathbf{N}$ & $\%$ & $\mathbf{N}$ & $\%$ & $\mathbf{N}$ & $\%$ & $\mathbf{N}$ & $\%$ & $\mathbf{N}$ & $\%$ & $\mathbf{N}$ & $\%$ & $\mathbf{N}$ & $\%$ & $\mathbf{N}$ & $\%$ & & \\
\hline ANAP+YP & 0 & 0 & 4 & 5,3 & 3 & 4 & 3 & 4 & 7 & 9,3 & 13 & 17,3 & 7 & 9,3 & 20 & 26,8 & 18 & 24 & 0 & 0 & 75 & 100 \\
\hline $\begin{array}{l}\text { DSP+YTP+ } \\
\text { CHP+ÖDP }\end{array}$ & 0 & 0 & 0 & 0 & 4 & 3,2 & 6 & 4,8 & 10 & 7,9 & 15 & 11,9 & 20 & 15,9 & 27 & 21,4 & 41 & 32,5 & 3 & 2,4 & 126 & 100 \\
\hline DYP & 2 & 2,4 & 33 & 40,3 & 38 & 46,4 & 5 & 6,1 & 0 & 0 & 2 & 2,4 & 0 & 0 & 1 & 1,2 & 1 & 1,2 & 0 & 0 & 82 & 100 \\
\hline $\mathrm{MHP}+\mathrm{BBP}$ & 0 & 0 & 5 & 3,8 & 4 & 3,1 & 9 & 6,9 & 5 & 3,8 & 20 & 15,2 & 16 & 12,2 & 34 & 26 & 35 & 26,7 & 3 & 2,3 & 131 & 100 \\
\hline $\mathrm{SP}+\mathrm{AKP}$ & 0 & 0 & 91 & 85,9 & 9 & 8,5 & 0 & 0 & 0 & 0 & 2 & 1,9 & 2 & 1,9 & 1 & 0,9 & 1 & 0,9 & 0 & 0 & 106 & 100 \\
\hline BAĞIMSIZ & 1 & 3,6 & 8 & 28,6 & 2 & 7,1 & 2 & 7,1 & 2 & 7,1 & 4 & 14,3 & 4 & 14,3 & 0 & 0 & 5 & 17,9 & 0 & 0 & 28 & 100 \\
\hline
\end{tabular}


Yine iktidar partisi milletvekillerinin oldukça aktif bir tutum sergiledikleri görülmektedir. 7'den fazla öneri veren milletvekilleri içinde, ANAP + YP grubu \%50; $\mathrm{MHP}+\mathrm{BBP}$ grubu \%55; DSP+YTP+CHP+ÖDP grubu ise \%56.3 gibi yüksek oranlı katılım göstermişlerdir. $\mathrm{MHP}+\mathrm{BBP}$ grubu istisna edilirse, iktidar milletvekilleri için diger konularda bu kadar aktif bir tutum gözlenmemektedir. Buna karşılık muhalefet partileri daha pasif bir tutum içindedirler.

SP+AKP grubu milletvekillerinin \%85.9'u yalnızca 1 önergeye imza atmışlardır. DYP'de ise 1 ve 2 önergeye imza atan milletvekili oranı \%86'yı bulmaktadir.

Parti politikalarına uyum ile anayasa değişikleri konusunda milletvekili rolleri arasında elde edilen sonuçlarda farklılıklar bulunmaktadır. Parti politikalarına uyumda daha pasif görünen ANAP milletvekillerinin, anayasa değişiklerinde oldukça aktif oldukları, yine $\mathrm{DSP}+\mathrm{YTP}+\mathrm{CHP}+\mathrm{ÖDP}$ grubunun da benzer şekilde aktif tutum sergilediği görülmektedir. Bunda anayasa değişikliklerinde genellikle iktidar partilerinin inisiyatifinde şekillenmesi, dolayısıyla $1 / 3$ çoğunluk koşulu nedeniyle gruplarını bu yönde harekete geçirmiş olmalarının rolü olduğu gibi, değişikliklerin arka planında $A B$ 'ye uyum çabalarının bulunduğu düşünüldüğüunde, özellikle ANAP'ın parti politikasıyla da çakıştığı belirtilebilir. Genel olarak katılmama oranlarındaki düşüklük partilerin gruplarını harekete geçirmede oldukça etkili olduklarının bir göstergesi olarak değerlendirilebilir. Parti politikalarına uyum konusunda dışarıda kalan milletvekili sayısının anayasa değişiklik önergelerine göre biraz daha fazla olması, bu konulardaki önerilerde imza sayısı koșulu bulunmamasında aranmalıdır. Yasal zorunluluk bulunduğunda, parti grubunu aktifleştirmektedir.

Parti politikalarına uyum konusunda muhalefet partilerinin, milletvekillerini daha aktif bir biçimde harekete geçirdikleri, buna karşılık anayasa değişiklerinde iktidar partilerinin öne geçtiği görülmektedir. Bunda muhalefet partilerinin etkinlik alanının meclis, iktidar partilerinin ise hükümet fonksiyonlarında yoğunlaşmış olmasının da rolü bulunmaktadır. Dolayısıyla parti politikalarının gündeme gelmesinde muhalefet partileri için meclis etkinliği, dolayısıyla grubun bu doğrultudaki aktif tutumu daha önem kazanmaktadır. 21. Dönem için MHP+BBP grubunun her iki açıdan da aktif bir tutum içinde bulunduğunun altının çizilmesi gerekmektedir. $\mathrm{Bu}$ grup hem parti politikalarına uyum, hem de anayasa değişikliklerinde grubunu aktif bir biçimde harekete geçirmiştir. Bu partinin, hükümet etkinliği yanında, parti grubunu yasama etkinliği içinde de aktif kıldığını göstermektedir.

Parti politikalarına uyum ve anayasa değişiklerinde aktif bir katılım sergileyen milletvekilleri, siyasal hayatın düzenlenmesine ilişkin önerilere imza atmak konusunda benzer bir tutum göstermemişlerdir. Bu konuda 21 . dönem yasama etkinliği oldukça sınırlı kalmış, sınırlı sayıdaki girişime de aktif bir katılım gösterilmemiştir (Tablo 23).

Meclis'in \%85.8'i bu tip herhangi bir yasa öneri imza vermemiştir. Partilerin katılmama eğilimi de \%60'ın üzerindedir. DSP+YTP+CHP+ÖDP grubunda bu \%97'yi, MHP + BBP grubunda \%93'ü, DYP'de \%87'yi bulmaktadir. Oransal olarak en aktif grup SP + AKP grubudur. Bu grubun katılım oranı \%30'u bulmaktadır. (Meclis'in \%15.7'si). İktidar partileri içinde ANAP bu konularda biraz daha aktif bir tutum sergilemiştir.

\section{SONUÇ}

21. dönem yasama etkinliği genel olarak değerlendirildiğinde, anayasa değişiklik önergeleri dışarıda bırakılırsa, Milletvekillerinin daha çok yerel çıkarlarla ulusal düzenlemelere dönük önerilerin üzerinde yoğunlaştığı, uğraş alanına ait çıkar ve siyasal hayatın düzenlenmesine ilişkin konularda daha pasif bir tutum sergiledikleri belirtilebilir. Genel etkinlik profilinde, Meclis'in sol kanadının en pasif grubu oluşturduğu, bu grubu iki merkez sağ partinin izlediği görülmektedir. $\mathrm{SP}+\mathrm{AKP}$ grubu içinde Meclis yasama etkinliğine katılmayan milletvekili bulunmamaktadır. Genel etkinlik açısından Meclis'in en sağında yer alan partiler daha aktif bir tutum sergilemişlerdir.

Tablo.23: Milletvekilinin Partisi/Siyasal Partiler, Seçim ve Milletvekili Davranışı

\begin{tabular}{|c|c|c|c|c|c|c|c|c|c|c|c|c|}
\hline & \multicolumn{2}{|c|}{0} & \multicolumn{2}{|c|}{1} & \multicolumn{2}{|c|}{2} & \multicolumn{2}{|c|}{3} & \multicolumn{2}{|c|}{5} & \multirow[t]{2}{*}{$T$} & \multirow{2}{*}{$\begin{array}{l}\mathbf{T} \\
\%\end{array}$} \\
\hline & $\mathbf{N}$ & $\%$ & $\mathbf{N}$ & $\%$ & $\mathbf{N}$ & $\%$ & $\mathbf{N}$ & $\%$ & $\mathbf{N}$ & $\%$ & & \\
\hline ANAP+YP & 59 & 78,7 & 2 & 2,7 & 13 & 17,3 & 1 & 1,3 & 0 & 0 & 75 & 100 \\
\hline $\begin{array}{l}\text { DSP+YTP+ } \\
\text { CHP+ÖDP }\end{array}$ & 123 & 97,6 & 2 & 1,6 & 0 & 0 & 1 & 0,8 & 0 & 0 & 126 & 100 \\
\hline DYP & 72 & 87,9 & 4 & 4,9 & 3 & 3,6 & 3 & 3,6 & 0 & 0 & 82 & 100 \\
\hline $\mathrm{MHP}+\mathrm{BBP}$ & 122 & 93,1 & 6 & 4,6 & 2 & 1,5 & 1 & 0,8 & 0 & 0 & 131 & 100 \\
\hline SP+AKP & 74 & 69,8 & 25 & 23,6 & 6 & 5,7 & 0 & 0 & 1 & 0,9 & 106 & 100 \\
\hline BAĞIMSIZ & 20 & 71,4 & 5 & 17,8 & 2 & 7,2 & 1 & 3,6 & 0 & 0 & 28 & 100 \\
\hline
\end{tabular}


Ulusal boyutta düzenleme içeren önergelerde, yukarıdakinin aksine, Meclis'in sol kanadı daha aktif bir eğilim göstermektedir. Bu alanda en pasif grup MHP+BBP grubudur. Söz konusu yerel çıkarlar olduğunda roller değişmektedir. En sağdaki partiler yerel çıkarlarla ilgili oldukça aktif bir etkinlik profiline sahiptirler. Bu konuda en pasif grubu Meclis'in sol kanadi oluşturmaktadır. Yerel çıkarlar konusunda duyarlı olan sağ partiler, uğraş alanına ait çıkarlar konusunda kendi içlerinde farklılaşmaktadırlar. Uğraş alanına ait çıkarlar konusunda Meclis içindeki en duyarlı grup MHP+BBP grubudur. SP+AKP grubu ise bu alanda pasif bir tutuma sahiptir. MHP kadar olmasa da Meclis'in sol kanadının uğraş alanına ait çıkarlarla ilgili belli bir duyarlılığa sahip bulundugu belirtilebilir.

Parti grubu ile yasama etkinliği ilişkisine bakıldığında, anayasa değişiklik önergelerinde iktidar partilerinin gruplarını daha aktif bir biçimde harekete geçirdikleri görülmektedir. Buna karşılık sözkonusu parti politikalarına uyum olduğunda, ibre muhalefet partilerine kaymaktadır. Özellikle SP+AKP grubu, Meclis'i parti politikalarını gündeme getirmekte oldukça aktif biçimde kullanmıştır. İktidar partileri içinde MHP+BBP grubunun istisnai bir durumu söz konusudur. $\mathrm{Bu}$ parti her iki konuda da grubunu aktif bir biçimde harekete geçirmiştir. Başka bir deyişle hükümet etkinliğinin öne çıktığı anayasa değişiklerinde parti grubunu aktif bir biçimde kullandığı gibi, parti politikaları ile ilgili Meclis platformunu kullanmak konusunda da bu parti milletvekilleri aktif bir tutum içinde olmuşlardır. Siyasal hayatın düzenlenmesi ile ilgili pasif bir tutumun Meclis etkinliğine hakim olduğu belirtilebilir.

Genel olarak 21. Dönemde, sol ve merkez sağ partilerin Meclis yasama etkinliğinde en sağdaki partilere göre daha pasif bir tutum içinde oldukları, yerel çıkarlar konusunda en sağdaki partilerin oldukça duyarlı oldukları, yine bu partilerin parti politikalarını gündeme getirmekte Meclis'i daha aktif bir biçimde kullandıklarını, buna karşılık Meclis'in sol kanadının ulusal düzenlemeler ve uğraş alanına ait çıkarlar konusunda daha aktif bir milletvekili bileşimine sahip bulunduğunu belirtebiliriz.

Milletvekillerinin seçildikleri bölge açısından yasama etkinliklerine bakıldığında, ulusal düzenlemeler ve uğraş alanına ait çıkarlara yönelik önergelerde Ege ve Marmara Bölgelerinden gelen milletvekillerinin, buna karşılık, yerel çıkarlar konusunda Karadeniz ve İç Anadolu Bölgelerinden gelen milletvekillerinin daha aktif bir katılım sergiledikleri görülmektedir. Güneydoğu Anadolu Bölge milletvekilleri ise tüm alanlarda en pasif milletvekili grubunu oluşturmaktadırlar. $\mathrm{Bu}$ grubun parti politikalarına uyum konusunda da en isteksiz bölgeyi oluşturdukları görülmektedir.
Genel yasama etkinliği göz önüne alıdığında büyük kenlerden gelen milletvekillerinin pasif bir tutum sergiledikleri, buna karşılık, uğraş alanına ait çıkarlar ve ulusal düzenlemeler konusunda diğer illere göre daha duyarlı bir yaklaşım sergiledikleri belirtilebilir.

Uğraş alanları açısından yasama etkinliğinde, ulusal düzenlemelerde hukukçu milletvekillerinin daha aktif bir tutum sergiledikleri, yine ulusal düzenlemelerde bürokrat ve öğretim üyesi milletvekillerinin oldukça aktif bir grubu içlerinde barındırdıkları belirtilebilir. Söz konusu yerel çıkarlar olduğunda, memur-öğretmenler, tüccarlar ve sağlık uğraş alanı gruplarının oldukça aktif oldukları, ögrretim üyelerinin de yerel çıkarlar konusunda duyarlı bir tutum içinde bulundukları söylenebilir. uğraş alanına ait çıkarlar konusunda en aktif uğraş alanı grubu mali müşavir ve muhasebecilerdir. Bu konuda çiftçilerin de aktif bir katılım gösterdikleri belirtilebilir. Parti politikalarına uyum konusunda yerel çıkarlarda olduğ gibi, memur-ögretmenler ve sağlık uğraş alanı gruplarının en uyumlu, buna karşılık çiftçilerin en isteksiz grubu oluşturdukları görülmektedir. Yine parti politikalarına uyum konusunda hukukçu milletvekilleri aktif bir katılım içinde olmuşlardır.

\section{YARARLANILAN KAYNAKLAR}

[1] KALAYCIOGLU, E., Çă̆daş Siyasal Bilim, Beta, İstanbul, 1984, s.382.

[2] KALAYCIOGLU, E., "Türk Yasama Sistemi ve Siyasal Temsil", E. KALAYCIOGLU - A.Y. SARIBAY (Der), Türk Siyasal Hayatının Gelişimi, Beta, İstanbul, 1986, ss.322-327.

[3] KALAYCIOĞLU, E., "The Grand National Assembly of The Post-1983 Multi-Party Era”. E. ÖZBUDUN (Ed.), Perspectives on Democracy in Turkey, Turkish Political Science Association, Ankara, 1988, ss.149-192.

[4] KALAYCIOĞLU, E., “Türkiye'de Politik Rejimin Evrimi ve Yasama Sistemi", E. KALAYCIOĞLU - A.Y. SARIBAY (Der), Türkiye'de Politik Değișim ve Modernleşme, Alfa, İstanbul, 2000, s.282.

[5] KIŞLALI, A.T., Siyaset Bilimi, İmge, Ankara, 1997, s.273.

[6] ÖZBUDUN, E., 2001 Anayasa Değişiklikleri ve Siyasal Reform Önerileri, Tesev, İstanbul, 2002.

[7] RANNEY, A., Governing- An Introduction to Political Science, Prentice Hall, New Jersey, 1990, ss.278-279.

[8] TURAN, İ., Siyasal Sistem ve Siyasal Davranıș, Der, İstanbul, 1986, ss.172-173. 
[9] TURAN, I.,, "Stages of Political Development in the Turksih Republic", E. ÖZBUDUN (Ed.), Perspectives on Democracy in Turkey, Turkish Political Science Associaion, Ankara, 1988, ss.90-91.

[10] YÜCEKÖK, A.N., Türkiye'de Parlamentonun Evrimi, AÜSBF Yay: 533, Ankara, 1983, s.206.

[11] TBMM Web Sitesi 21. Dönem Üye Listeleri http://www.tbmm.gov.tr/develop/owa/milletvekili.liste21?

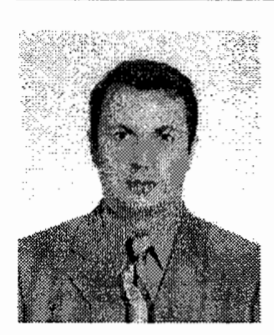

Haluk ALKAN

Kahramanmaraş Sütçü İmam Üniversitesi İIBF Kamu Yönetimi Bölümü 46100 Kahramanmaraş

Tel: $+90(344) 2237666-367$ halukalkan@ksu.edu.tr

Dr. Haluk ALKAN is Assistant Professor of Political Sciences at Kahramanmaras Sutcu Imam Unıversity. He received his Ph.D from Marmara Unıversity. His research areas include political regimes, pressure groups and policy making.

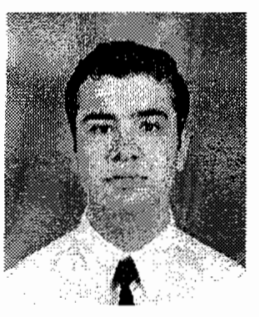

\section{Nuh ATES}

Kahramanmaraş Sütçü İmam Üniversitesi SBE Kamu Yönetimi A.B.D. 46100 Kahramanmaras

Tel: +90 (344) $2237666-375$ nuhates@yahoo.com

Nuh ATES is Research Assistant at Kahramanmaras Sutcu Imam University. Currently he is a master student at the same university. His research areas include political participation, estate, e-democracy. 